\title{
Characterization of Plant Communities Adjacent to the B-C Cribs Controlled Area and Redox Pond Areas on the 200 Area Plateau
}

January 1975

Prepared for the U.S. Energy

Research and Development Administration

under Contract AT(45-1):1830 

BNWL-1916

UC-70

Special Distribution

\begin{abstract}
33679000463929
CHARACTERIZATION OF PLANT COMMUNITIES ADJACENT TO

THE B-C CRIBS CONTROUED ARE AND REDOX POND

AREAS ON THE 200 AREA PLATEAU
\end{abstract}

J. F. Cline, D. W. Uresk, and W. H. Rickard

Ecosystems Department

January 1975

This report was sponsored

by

The Atlantic Richfield Hanford Company under Uni.ted States Energy Research and

Development Administration

Contract AT(45-1)-2130

\title{
BATTELLE
}

PACIFIC NORTHMEST LABORATORIES,

RICHLAND, WASHINGTON 99352 
BNWL-1916

\section{CONIENTS}

SLMMAY ........................... 1

ACANOMEDGMENT . . . . . . . . . . . . . . . . . . 4

CHAPTER 1 INTRODUCTION . . . . . . . . . . . . 5

Purpose .................... . . . 5

Site Description . . . . . . . . . . . 5

Relationship of the Study Sites to the Natural Vegetation

Mosaic of the Hanford Reservation . . . . . . . 6

Methods Employed .............. . 7

CHAPTER 2 VEGETATION ANALYSES . . . . . . . . . 12

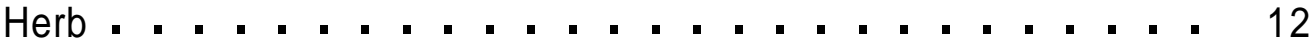

Shrub . . . . . . . . . . . . . . . . . . 13

Belowground Biomass . . . . . . . . . . . . . . . 14

Statistical Evaluation of Data . . . . . . . . . 14

Relationships to Other Plant Communities . . . . . . . 16

Environmental Stresses - Fire and Grazing . . . . . 17

CHAPTER 3 SOIL-PLANT RELATIONSHIPS . . . . . . . . . . 30

Soil Properties (Physical) . . . . . . . . . . 30

Soil Properties (Chemical) . . . . . . . . . . . . 31

Mineral Content of Plants . . . . . . . . . . . 32

Radionuclide Availability in Surface Soil . . . . . 32

LITERATURE CITED . . . . . . . . . . . . . . . . 42

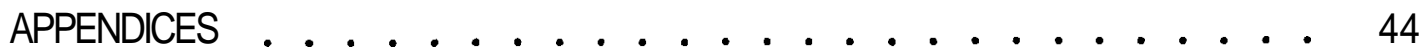




\section{SUMMRY}

The plant communities studied at the B-C Cribs Controlled area and REDOX study areas are probably very much like the communities that existed prior to 1943 when the Hanford Reservation was established. However, due to overgrazing by domestic animals, the communities are not in the same condition as they were prior to 1800 (Daubenmire 1970). The major vegetational change has been the incorporation of weeds of European origin into the plant community. The most successful of these European weeds is cheatgrass, and it has probably been a member of the plant community for a century. This grass was an important plant on Benton County rangelands a half century ago (St. John and Jones 1928). Cheatgrass is so well adapted to the climatic and soil conditions of the Hanford Reservation that it is prudent to consider the species as an integral part of the flora and to make use of its pioneering aggressiveness in revegetating disturbed land.

Although sagebrush has a reputation of being an aggressive invader of rangelands, it has not invaded abandoned agricultural fields on the Hanford Reservation after 30 years. Sagebrush has also been slow to invade areas burned 15 years ago, indicating its susceptibility to fire damage.

Russian thistle is the most troublesome plant as far as waste burial is concerned. It can develop an extensive root system and has the ability to accumulate radionuclides from soil more effectively than other kinds of plants. Whole plants tend to break off at the soil surface when mature and these can be transported several miles by wind. Although present in the sagebrush and cheatgrass dominated plant communities at the B-C and REDOX study sites, it is more plentiful on the disturbed soils of waste burial grounds. 
Extensive plant communities of the 200 Area plateau are comprised of short-statured evergreen shrubs with an understory consisting of small herbaceous plants. Sagebrush, Artemisia tridentata, is the abundant shrub

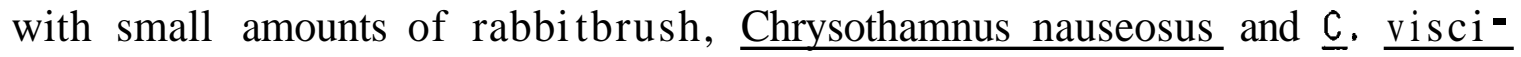
diflorus, intermingled with sagebrush. Two study sites were examined in detai1. One study site was adjacent to the B-C Cribs Controlled Area and the other was located adjacent to a former REDOX cooling water disposal facility. Shrub canopies occupied 26\% of the ground area at the B-C Cribs Controlled Area and 20\%at the REDOX site. The number of shrubs per 1000 $\mathrm{m}^{2}(0.25$ acre $)$ was 376 at the B-C Cribs Controlled Area and only 110 at the REDOX site. The average sagebrush plant was $8.5 \mathrm{dm}$ (33 inches) tall at the B-C site and 11.5 dn (45 inches) tall at the REDOX site.

The ground beneath and between the canopy spread of shrubs was occupied by sparse stands of herbs. Ground cover provided by living herbs was $37 \%$ at the B-C site and 38\% at REDOX. About $60 \%$ of the ground was not occupied by herb canopies.

Twenty-nine widespread and common herbaceous plant species were recorded after examination of 800 one-tenth square meter plots. More than $80 \%$ of the total canopy-cover provided by herbs was contributed by annual plants; perennial plants contributed the remainder. Cheatgrass, Bromus tectorum, was the most abundant herb. Alone, cheatgrass accounted for $40 \%$ of the herbaceous cover at the B-C site and 60\% at REDOX. Perennial grasses and forbs provided 18 of the 29 species. The number of plant species encountered in the study area was less in comparison to other kinds of natural plant communities in eastern Washington. 
The amount of dry matter produced by the understory plants at the B-C site during 1974 averaged $40 \mathrm{~g} / \mathrm{m}^{2}$. This estimate is lower than the $65 \mathrm{~g} / \mathrm{m}^{2}$ and the $360 \mathrm{~g} / \mathrm{m}^{2}$ of dry matter produced in perennial and annual grass communities, respectively, of the ALE Reserve.

The conclusion is that species diversity and net productivity are lower than other plant communities of eastern Washington. Daubenmire (1970) states that other eastern Washington communities may have over a hundred species. The 200 Area plateau is included in Daubenmire's definition of a desert region, while most of the ALE Reserve is transitional steppe or steppe region. A steppe region of eastern Washington must produce at least $70 \mathrm{~g} / \mathrm{m}^{2}$ of dry matter while a desert region produces considerably less. A desert region is considered too dry to support a noticeable cover of perennial grasses on zonal soils, and annual plants predominate. Perennial grasses are scarce, and it is unlikely that these grasses were an important part of the 200 Area plateau plant communities. The aggressive annual grass, Bromus tectorum, is now and will probably continue to be the most important herb species for many years unless there are dramatic changes in climate. In the event of fire, the herbaceous species will recolonize the burned areas. Russian thistle wil1 be an important species in the early recolonization stages, but cheatgrass will provide the greatest amount of ground cover for many years. 


\section{ACKNOWLEDGMENT}

The authors wish to thank R. 0. Gilbert for his assistance with the statistical analyses. 


\section{CHARACIERZATION OF PLANT COMMUNIIES ADIACENT TO \\ THE B-C CRIBS CONIROUHD AREA AND REDOX POND \\ AREAS ON THE 200 AREA PLATEAU \\ J. F. Cine, D. W. Uresk and W. H. Ri ckard}

CHAPTER 1

\section{NIRODUCTION}

\section{PURPOSE}

The purpose of this investigation was to characterize the important plant communities on the 200 Area plateau with particular reference to the B-C Cribs Control led Area (a waste burial zone) and the REDOX area (an inactive pond).

\section{SITE DESCRIPIION}

The 200 Area plateau is centrally located on the Energy Research and Development Administration's Hanford Works Reservation, Benton County, Washington (Figure 1.1). The plateau consists of about 40,000 acres of mostly undeveloped land located between the Rattlesnake Hil1s and Gable Mountain. The average elevation of the plateau is about 700 feet above mean sea level The topography is gently undulating and lacks well defined surface drainage channels. Sand dunes are present in scattered locations but are not extensive. The highest dunes are 10-15 feet above the normal elevation. Four small ponds, U-Pond, B-Pond, Gable Mountain Pond, and West Lake presently occur on or near the plateau (Figure 1.2). All ponds except West Lake 
receive aqueous discharges from the cluster of large buildings that coniprise the $200 \mathrm{E}$ and $200 \mathrm{~W}$ areas. The climate of the plateau has been continuously monitored at the Hanford Meteorological Station located between the 200E and 200W areas since 1943 (Stone, Jenne, and Thorp 1972).

The location of study sites is shown in Figure 1.2. The study site is located outside of the B-C Cribs Controlled area and is designated as B-C Cribs.

RELATIONSHIP OF THE STUDY SITE TO THE NATURAL VEGETATION MOSAIC OF THE HANFORD RESERVATION

Three major vegetation types can be mapped on the Hanford Reservation west of the Columbia River (Figure 1.3). (1) The sagebrush-bitterbrush/ Sandberg bluegrass-cheatgrass type occupies a triangular area with its apex near the $100 \mathrm{~F}$ reactor site and extending southward to the 300 Area and southwesterly to the Horn Rapids Bend of the Yakima River. The important shrub species are big sagebrush, Arteniisia tridentata, and bitterbrush, Purshia tridentata. Other shrubby species are rabbitbrush, Chrysothamnus

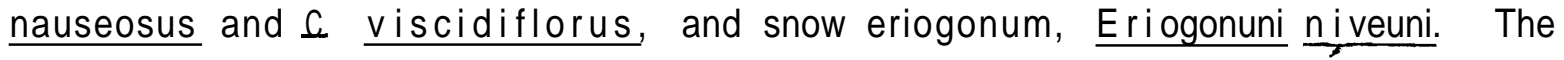
herbaceous understory is usually sparse and dominated by grasses, especially cheatgrass, Bromus tectorum, and Sandberg bluegrass, Poa sandbergi i. The sagebrush/bluebunch wheatgrass-Sandberg bluegrass vegetation type is confined to the Rattlesnake Hills at elevations above 900 feet (Figure 1.3). Big sagebrush is the dominant shrub. The herbaceous understory is dominated by the large perennial bluebunch wheatgrass, Agropyron spicatum. Sandberg bluegrass is ubiquitous. In pristine condition cheatgrass is absent. (3) The vegetation type between the two above-1isted types is the sagebrush/cheatgrass-Sandberg bluegrass vegetation type. This type occupies most of the 
200 Area plateau. It differs from the sagebrush-bitterbrush type by lacking bitterbrush. The almost total absence of bluebunch wheatgrass distinguishes it from the sagebrush-bluebunch wheatgrass type.

\section{METHODS EMPLOYED}

The experimental design consisted of two replicated sample areas in each of two separate sites, i.e., B-C and REDOX. Each replicate consisted of four 50-meter transects arranged parallel to each other and systematically spaced at 30 -meter intervals. Shrub density was estimated by counting a11 individuals rooted inside a $10 \times 50 \mathrm{~m}\left(500 \mathrm{~m}^{2}\right)$ study plot in each replicated area. Each shrub was measured for long and short diameters and also extreme shoot height from ground level. Canopy-cover provided by herbaceous taxa was measured by reading fifty, $2 \times 5 \mathrm{dm}$, plot frames systematically spaced at one-meter intervals on each Iine transect. In a11, 400 plots were read at each site. Canopy cover for each taxon was ocularly estimated using a modified method developed by Daubenmire (1959). Modified classification numbers were $1<5 \%, 2=5-15 \%, 3=15-25 \%, 4=25-50 \%$, $5=50-75 \%$, and $6=75-100 \%$. Frequency of occurrence was calculated as percentage of the total number of examined plots in which a particular taxon was present (Hyder et al 1966).

Aboveground biomass was estimated by hand-clipping herbaceous plants located within a $0.5 \mathrm{~m}^{2}$ circular plot. Four plots were systematically spaced at 10 -meter intervals along eachline transect. Live material representing the current year's growth was hand separated from dead plant material. All material was oven-dried at $60^{\circ} \mathrm{C}$ and weighed to the nearest one-hundredth of a gram. The plant material was ground in a Wiley mill to pass through a one $\mathrm{mm}$ screen mesh and chemically analyzed for macro- and micronutrient content by the United States Testing Company, Richland, Washington. 
Belowground biomass was obtained by collecting soil cores, $8.6 \mathrm{~cm}$ in diameter, from the upper meter of profile. Increments, each $10 \mathrm{~cm}$ long, were taken to provide a measure of the distribution of roots within the soil profile. Each soil increment was washed in running water and the roots retained on a fine mesh screen. Roots were floated to eliminate heavy mineral particles. Root biomass was expressed as an ash-free dry weight to account for surface held particles associated with dry weight of roots. Ashing was done at $500^{\circ} \mathrm{C}$ over a 24 -hour period. Sixteen cores were taken on the B-C Cribs area, but none were taken in the REDOX area.

Four soil cores were taken in $10 \mathrm{~m}$ increments at each site to a depth of $60 \mathrm{~cm}$ using a sand auger. Air-dried soil samples were submitted to the United States Testing Company for textural and chemical analyses.

All field data and samples were obtained between Apri1 26 and May 6, 1974. Detailed analysis and summaries of field data are presented in Appendices 1-9. 


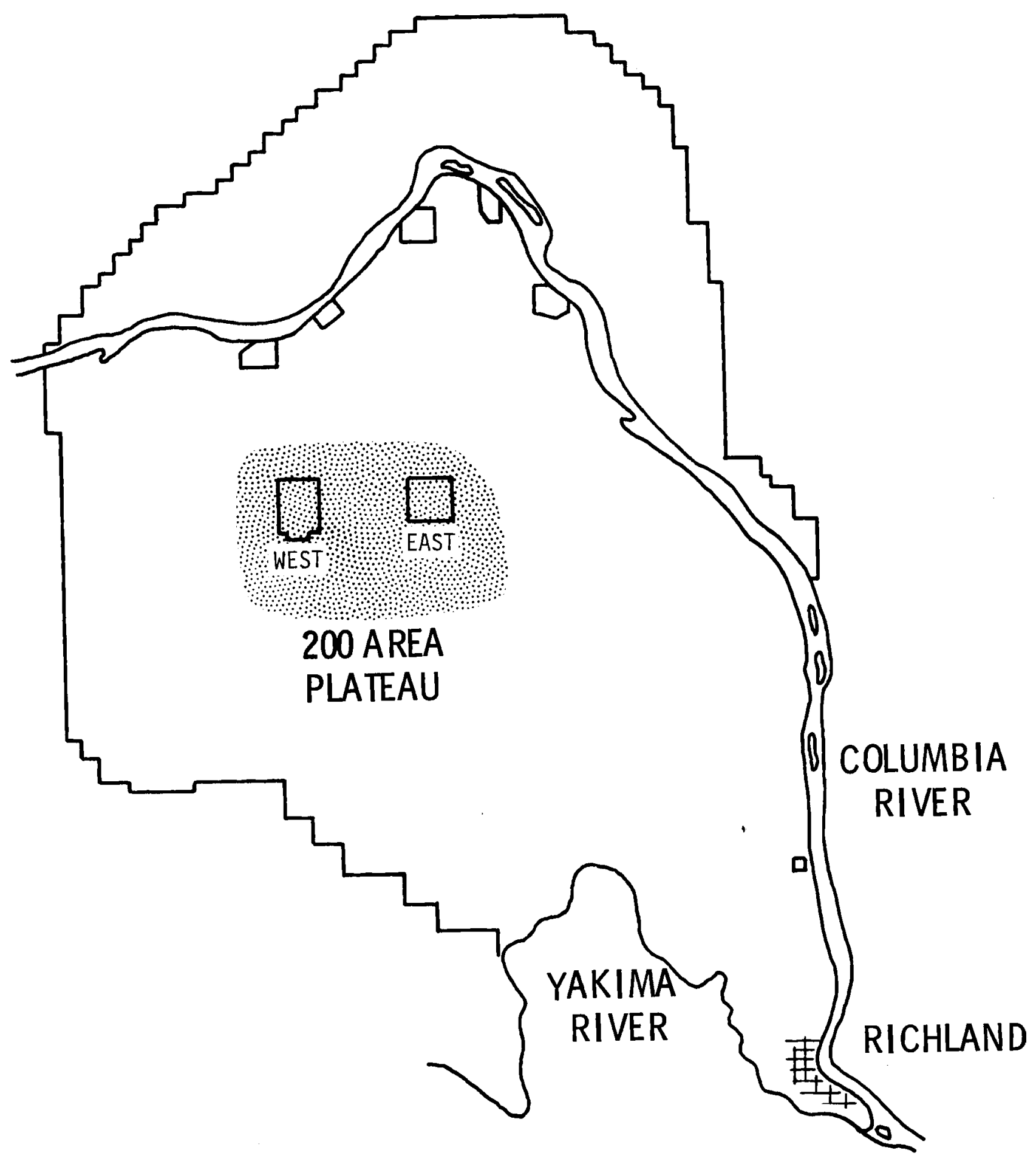

FIGURE 1.1. The location of the 200 Area plateau on the U.S.E.R.D.A. Hanford Works Reservation. 


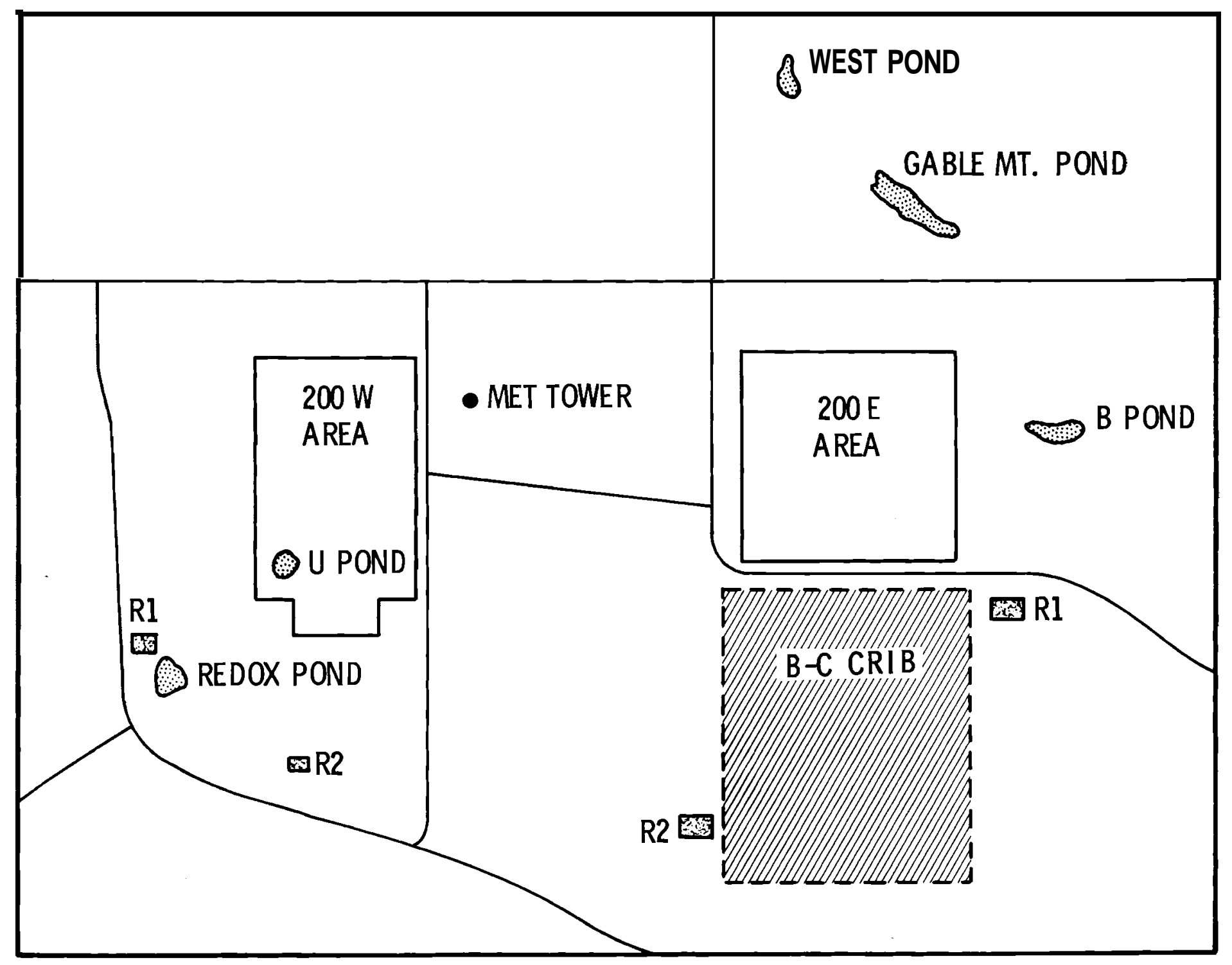

FIGURE 1.2. Location of the B-C Cribs and REDOX study sites (RT and R2) and associated facilities at the 200 Areas. 


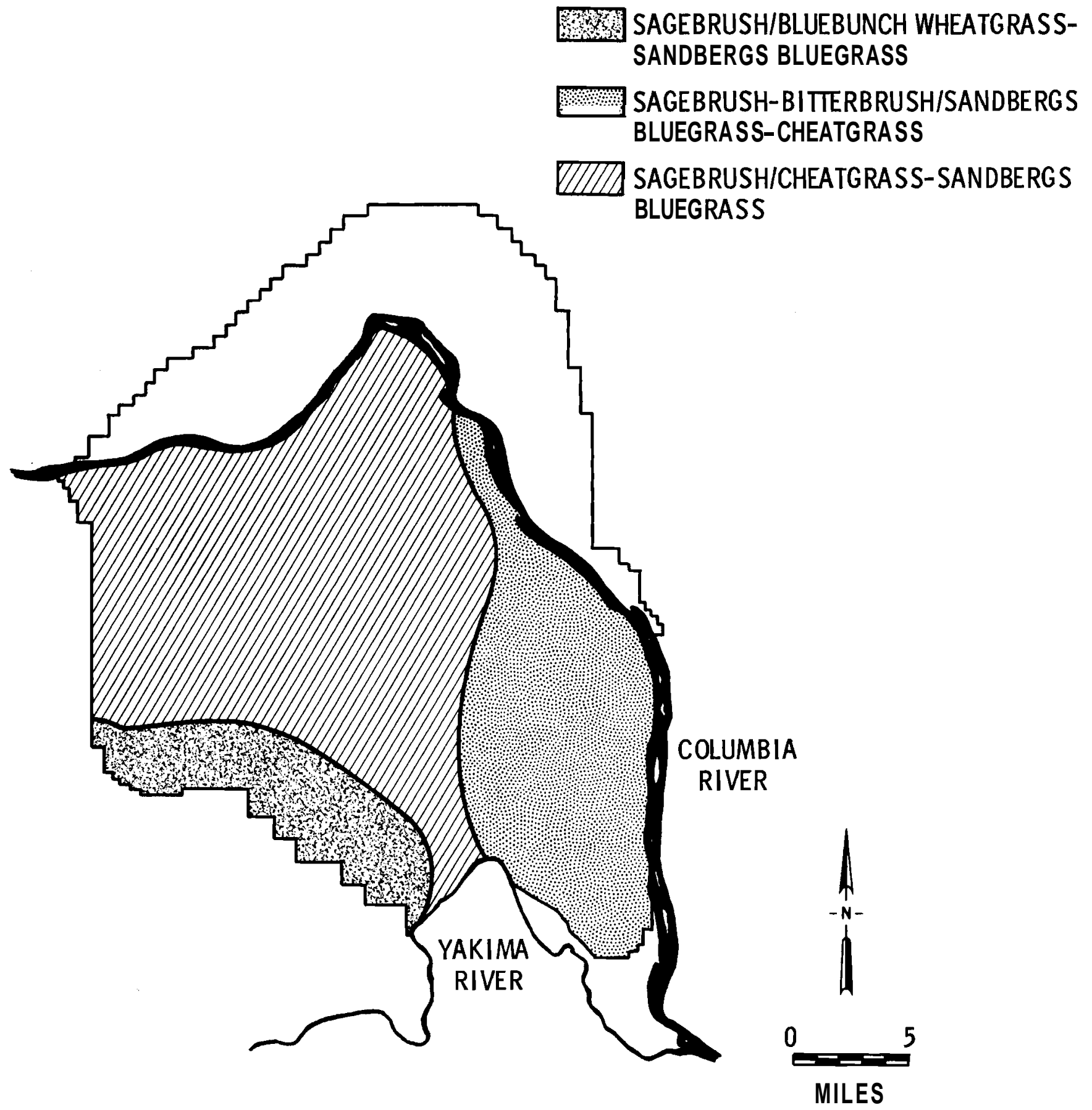

FIGURE 1.3. Boundaries of the three major vegetation types on the Hanford Reservation. 


\section{CHAPTER 2}

\section{VEGETATIONAL ANALYSES}

HERBS

Only 29 species (taxa) were observed on 800 plots (Table 2.1). Twentythree taxa occurred on the B-C Cribs area and 22 on the REDOX area. Annual grasses and forbs dominated canopy cover while perennial grasses and forbs provided 1ittle ground cover. Herbaceous understory cover was nearly identical in the B-C Cribs and REDOX areas, i.e., 37 and $38 \%$, respectively. More than $60 \%$ of the understory did not support herbs and was either bare or supported a cover of algae, moss, and lichen. Clearly, the most important herb was cheatgrass. It alone provided more than $50 \%$ of the total cover provided by herbs (Figure 2.1). It was widely distributed as indicated by its high frequency of occurrence- 94 to 95\%. Tansy mustard, Descurainia pinnata, was the most important annual forb. Plant nomenclature follows Hitchcock and Cronquist (1973).

Russian thistle, Salsola kali, is more important to canopy-cover than shown because of the season of the year in which the observations were recorded. Russian thistle grows throughout the summer attaining great size in late summer. All species other than Russian thistle listed in Table 2.1 show senescence or arrested growth before the onset of summer.

The live biomass (net primary production) of herbs by species is shown in Table 2.2. The data are available only for the B-C Cribs area but are not expected to be very different at the REDOX site. The total yield was about $40 \mathrm{~g} / \mathrm{m}^{2}$ dry weight or roughly 400 pounds per acre. This was much 
lower than that measured in a cheatgrass community without shrubs near the N Reactor site (Rickard 1974). It was also much lower than the average of $240 \mathrm{~g} / \mathrm{m}^{2}$ that was measured in cheatgrass swards on the Arid Lands Ecology Reserve (Cline and Rickard 1973). However, this is expected because of a more abundant precipitation regime associated with the ALE communities and the lack of competition.

\section{SHRUBS}

Shrubs are the conspicuous plants in the B-C Cribs and REDOX areas; however, only three species were present. These are sagebrush (Artemisia tridentata) and two species of rabbitbrush (Chrysothamnus nauseosus and $\mathcal{C}$ viscidiflorus). On the average there were fewer shrubs on the REDOX site than on the B-C Cribs site (Table 2.3). The average number of shrubs in the B-C Cribs area was $188 / 500 \mathrm{~m}^{2}$ as compared to only $54 / 500 \mathrm{~m}^{2}$ in the REDOX area. The more dense stand of shrubs did not affect the amount of cover provided by herbs (Table 2.1). The site with the greatest shrub density a]so supported the shortest statured and smallest diameter plants (Table 2.4).

An analysis of the distribution of various height classes that comprised the measured shrub population in the B-C and REDOX areas is shown in Figures 2.2 and 2.3. Clearly, many of the individuals, especially at B-C Cribs site, are grouped into the medium-statured classes with very few very short or very tall plants. The sizes ranged from less than $0.2 \mathrm{~m}$ to over $1.7 \mathrm{~m}$ in height.

Less canopy cover was provided by shrubs than by herbs (Table 2.5). Average shrub cover was $26 \%$ at the B-C Cribs and 20\% at the REDOX site. 


\section{BEIOWGROUND BIOMASS}

The total belowground biomass in the upper meter of soil profile was estimated at $368 \mathrm{~g} / \mathrm{m}^{2}$. More than half was in the upper $3 \mathrm{dm}$ of soil profile (Figure 2.4).

\section{STATIST1CAL EVALUATION OF DATA}

It is seldom feasible in field studies to make complete inventories or censuses of plant populations that may be spread over many acres or even square miles of landscape. Instead, smaller areas are selected for observation and enumeration. These selected sites are characterized by a number of small plots on which certain parameters are measured. A mean value is usually obtained and some estimate of the variance associated with this mean, usually standard error of the mean. This is particularly important for comparisons between different kinds of plant communities and for comparisons with data in the published scientific literature.

The experimental design for comparing the B-C Cribs and REDOX sites is a nested factorial design described by Snedecor and Cochran (1967). For multiple comparisons, a Bonferroni t-test was used (Miller 1946).

\section{Dry Weight (Biomass)}

Dry weight measurements are relatively precise and results can be compared directly over a broad range of plant communities from deserts to forests. Sometimes it is a matter of technical judgement as to what constitutes growth of the year. It is a particular problem in woody vegetation where twig harvests need to be made and where some of the current year's growth is added to stem circumference along the entire length of the plant. In perennial grasses, harvests are conventionally made by hand or machine clipping at or near the ground surface. Annual plants are the easiest to 
measure for annual production by harvest method since all the aboveground material is produced in the current year and tedious hand separation of dead plant material produced in early years is not needed as is the case for most perenni al species.

The standard error of the mean (SE) shows the variance associated with the mean. If the standard error is within a value of $10 \%$ of the mean, we can be reasonably confident of its validity. The mean of $40 \mathrm{~g} / \mathrm{m}^{2}$ with a standard error of 4.3 (Table 2.2) approaches this criterion. Much of the sample-to-sample variation is due to the hummocky microtopography causing patchy distribution of plant cover ranging from very dense stands to none at all over distances as short as one meter.

$\underline{\text { Shrub Hei ght Measurements }}$

Shrub height is a reasonably precise field measurement which is useful for comparing communities of similarly statured plants. Since a large sample size is used to calculate the mean, the standard error is small and the mean shows a close approximation to the true mean. However, the presence of a few very tall shrubs may be more important to certain wildlife than the average shrub. For example, meadowlarks often select the highest vegetation as perching posts. Likewise, low shrubs may be more important to browsing hares because they cannot reach the canopy of the tall shrubs. The height class distribution of shrubs is shown in Figures 2.2 and 2.3.

Shrub heights at both sites were more uniform than either shrub cover or any understory cover as shown by the lower coefficients of variation shown in Table 2.6. 
Shrub and Understory Measurements

The ecological variability among the various covers of the two sites can be compared using the coefficients of variation in Table 2.6. Cheatgrass cover was the least uniform measurement. This was due to cover measurements varying from nearly 100 to $0 \%$ cover. The total understory cover was more uniform. Sagebrush and rabbitbrush cover values were similar but slightly less variable than the cheatgrass cover.

Probability factors were calculated to establish differences and similarities in measurements at the two sites (Table 2.7). Cheatgrass cover, total understory cover minus cheatgrass cover, and shrub cover was significantly different between the sites. The total understory cover at the two sites was not different $(p \geq .50)$, and is due to the fact that cheatgrass cover was greater at REDOX site and cover provided by the other herbs was greater at the B-C Cribs site $(p \leq .01)$.

\section{RELATIONSHIP TO OTHER PLANT COMMUNITIES}

Plant communities in the B-C Cribs and REDOX areas are comprised of relatively few plant species as compared to steppe communities in more humid parts of Washington (Daubenmire 1970). There are also fewer plant species than found in the more arid Mojave desert of southern Nevada (Rickard and Beatley 1965). A7though the 1973-74 plant growth season was marked by better than average precipitation, the yield (production) of herbs was about $40 \mathrm{~g} / \mathrm{m}^{2}$. This is $75 \%$ lower than that of cheatgrass dominated swards on the Arid Lands Ecology project and about one-fourth of that reported for knob and kettle terrain at the $\mathrm{N}$-Reactor site on the Hanford Reservation (Rickard 1974). However, the yield was higher than that reported for herbaceous species in the Mojave desert (Beatley 1969). 
The canopy cover furnished by shrubs in the B-C Cribs area averaged $26 \%$, probably representing maximal values for the shrub-dominated communities on the Hanford Reservation. In sagebrush/bunchgrass communities on the ALE Reserve, shrub cover was less than 5\% (Price and Rickard 1972). In a study relating vegetation to beetle distribution, Rickard (1970) reported values ranging between 7 and $29 \%$. Two sagebrush communities in southern Nevada had values of 28 and $27 \%$ (Rickard and Beatley 1965).

The conclusion is that plant communities on the B-C Cribs and REDOX areas are comprised of relatively few plant species, i.e., species diversity is low. The most important herbaceous species is the alien winter annual grass, cheatgrass, and the most important shrub species is sagebrush.

ENVIRONMENTAL STRESSES - FIRE AN GRAZING

Wildfire is a common occurrence on the Hanford Reservation. Extensive range fires occurred in the summer of 1957, 1961, 1970, and 1973. The fire most closely related to B-C and REDOX vegetation was the 1970 burn which consumed an estimated 17,000 acres in the sagebrush-bitterbrush vegetation type located south and east of the 200 Area plateau (Rickard and Cline 1971).

General observations after the burn showed that sagebrush and bitterbrush were fire sensitive and did not sprout after burning. Perennial forbs and grasses were not so adversely affected by fire and in many instances survived the burning and sent out new shoots the spring following the burning. Rabbitbrush also had the ability to sprout from surface crowns. Annual plants were decimated in areas of extreme heat. The absence of standing dead 
herbaceous plant material and the demise of shrubs opened the area to wind erosion for many months after the fire. Wind erosion was marked by frequent dust clouds during periods of high wind speed for two years after the burn. Initial invasion of the burn was made by Russian thistle and by bursage, Franseria acanthicarpa. After four years, cheatgrass had regained dominance in many areas, although blowouts remain exposed to wind action and are still devoid of plant cover.

The influence that past livestock grazing (pre-1940) has had upon the vegetation on the 200 Area plateau is mostly conjecture. A commonly held belief is that perennial bunchgrasses were once abundant and associated with the 200 Area plateau and were adversely affected by overgrazing. It seems probable that perennial bunchgrasses did not occupy a significant part of the 200 Area plateau vegetation. This view is held by Daubenmire (1970) and is borne out by this study; perennial grasses are only a minor constituent of the vegetation even after more than 30 years of protection from grazing livestock. Other evidence that would support the belief that large perennial bunchgrasses are not to be expected here is the very low amount of rainfall associated with the 200 Area plateau. For example, the geographic distribution of bluebunch wheatgrass at the Hanford Reservation is associated with regions of higher annual rainfall than on the 200 Area plateau. 
TABLE 2.1. Herbaceous taxa, frequency of occurrence (\%F) and canopy cover $(\% \mathrm{C})$ in plant communities in the B-C and REDOX sites, 200 Area plateau, Hanford Reservation, 1974.

Taxa

$\frac{\text { B-C }}{\% \mathrm{Cribs}}$

$\frac{\text { REDOX }}{\% \mathrm{~F} \% \mathrm{C}}$

Annual Grasses

Bromus tectorum

Festuca octoflora

Total $(\% \mathrm{C})$

Perennial Grasses

Poa sandbergi i

Stipa comata

Sitanion hystrix

Agropyron spicatum

Agropyron dasytachyum

Poa canbyi

Total (\% C)

Perennial Forbs

Oenothera pal7ida

Aster sp.

Cymopterus terebinthinus

Erigeron filifolius

Calochortus macrocarpus

Mentzelía atbicaulis

Lupinus sp.

Phlax longifolia

Astraga7us sp.

Brodiaea douglasii

Comandra pa11i da

Balsamorhiza careyana

Total $(\% \mathrm{C})$

Annual Forbs

Descurainia pinnata

Cryptantha circumscissa

Sisymbrium altissimum

Salsola kali

Cryptantha pterocarya

Microsteris aracilis

Phacelia linearis

Amsinckia lycopsoides

Erodium cicutarium

Total (\% C)

TOTAL HERBACEOUS COVER

TOTAL TAXA

$(+=$ less than $.01 \%$ cover $)$

\begin{tabular}{|c|c|c|c|}
\hline $\begin{array}{l}94 \\
75\end{array}$ & $\begin{array}{r}15.3 \\
4.2 \\
\end{array}$ & $\begin{array}{l}95 \\
58\end{array}$ & $\begin{array}{r}21.9 \\
2.4 \\
\end{array}$ \\
\hline -- & 19.5 & -- & 24.3 \\
\hline $\begin{array}{r}22 \\
<1 \\
0 \\
3 \\
0 \\
0\end{array}$ & $\begin{array}{l}1.8 \\
0.2 \\
0 \\
0.2 \\
0 \\
0 \\
\end{array}$ & $\begin{array}{r}3 \\
10 \\
<1 \\
0 \\
5 \\
1\end{array}$ & $\begin{array}{c}0.3 \\
2.0 \\
\mathbf{t} \\
0 \\
0.7 \\
0.2 \\
\end{array}$ \\
\hline -- & 2.2 & -- & 3.2 \\
\hline $\begin{array}{c}<0.1 \\
0 \\
<1 \\
3 \\
1 \\
<1 \\
0 \\
4 \\
0 \\
1 \\
<1 \\
<1\end{array}$ & $\begin{array}{c}<0.1 \\
0 \\
0.3 \\
0.2 \\
+ \\
+ \\
+ \\
0.7 \\
0 \\
\mathbf{t} \\
\mathbf{t} \\
0.2 \\
\end{array}$ & $\begin{array}{c}<0.1 \\
3 \\
7 \\
11 \\
1 \\
1 \\
<1 \\
<1 \\
<1 \\
0 \\
0 \\
0\end{array}$ & $\begin{array}{c}<0.1 \\
0.3 \\
2.0 \\
0.3 \\
\mathbf{t} \\
\mathbf{t} \\
\mathbf{t} \\
\mathbf{t} \\
\mathbf{t} \\
0 \\
0 \\
0 \\
\end{array}$ \\
\hline -- & 1.4 & -- & 2.6 \\
\hline $\begin{array}{r}85 \\
49 \\
1 \\
4 \\
12 \\
65 \\
6 \\
1 \\
3\end{array}$ & $\begin{array}{r}8.1 \\
1.8 \\
<0.1 \\
0.2 \\
0.6 \\
3.3 \\
0.2 \\
<0.1 \\
0.2\end{array}$ & $\begin{array}{r}51 \\
56 \\
22 \\
8 \\
12 \\
1 \\
0 \\
0 \\
0\end{array}$ & $\begin{array}{c}3.4 \\
2.8 \\
1.4 \\
0.2 \\
0.7 \\
<0.1 \\
0 \\
0 \\
0\end{array}$ \\
\hline -- & 14.4 & -- & 8.5 \\
\hline -- & $\underline{\underline{37}}$ & -- & 38 \\
\hline 23 & & 22 & \\
\hline
\end{tabular}


TABLE 2.2. Aboveground live biomass $\mathrm{g} / \mathrm{m}^{2}$ of herbaceous plant taxa (mean $\pm \mathrm{SE}$ ) on study sites at the B-C Cribs site on the 200-Area plateau, Hanford Reservation, 1974.

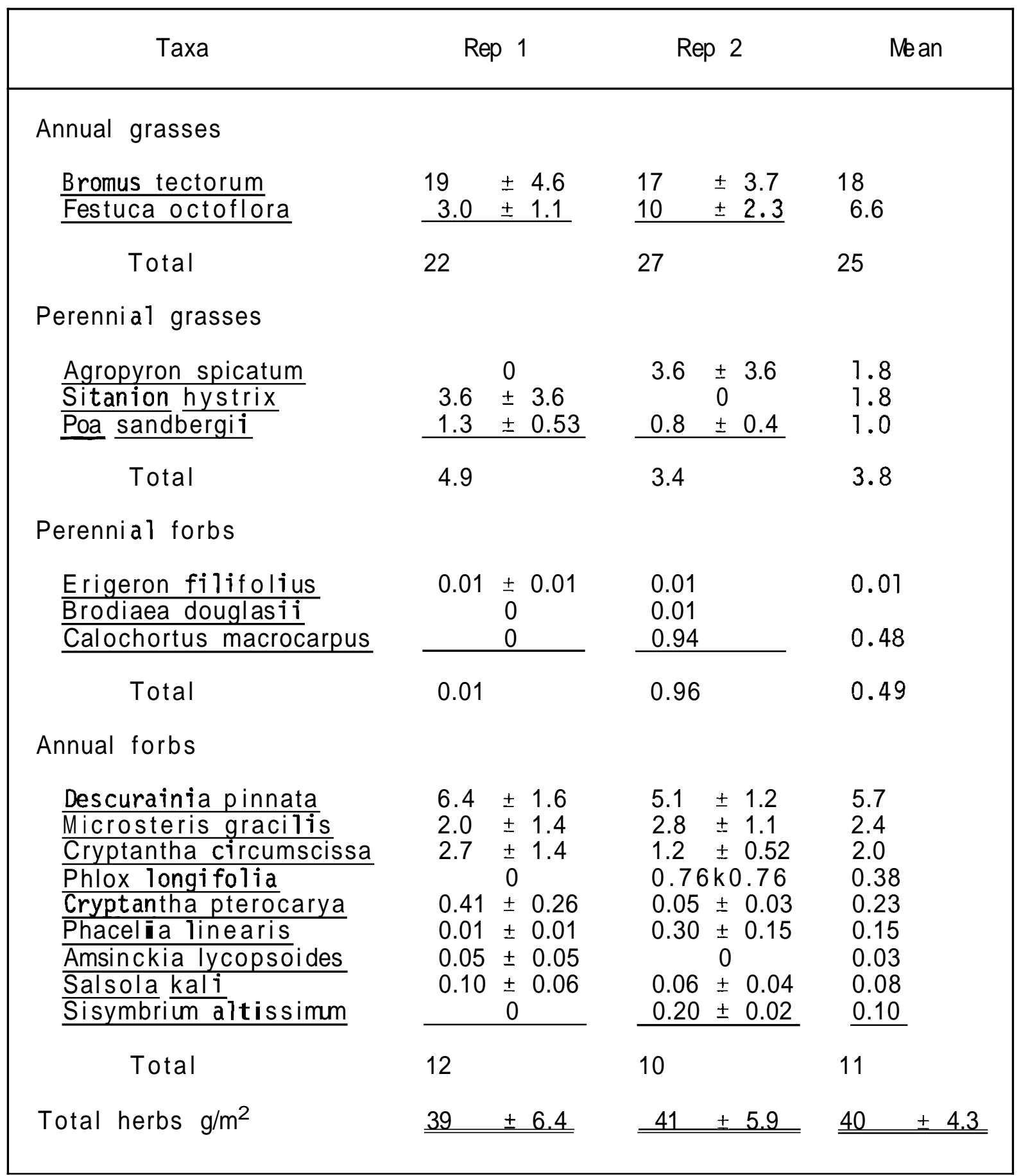


TABLE 2.3. Density of shrubs (numbers per $1000 \mathrm{~m}^{2}$ ) in the $B-C$ Cribs and REDOX areas.

\begin{tabular}{|crrrrrrr|}
\hline & \multicolumn{3}{c}{ B-C Cribs } & & \multicolumn{3}{c|}{ REDOX } \\
\cline { 2 - 5 } Taxa & Rep 1 & Rep 2 & Mean & & Rep 1 & Rep 2 & Mean \\
\hline Artemisi a & 226 & 518 & 372 & 94 & 76 & 84 \\
\hline Chrysothamnus & 0 & 8 & 4 & 14 & 36 & 26 \\
\cline { 1 - 4 } Total & 226 & 526 & 376 & 108 & 112 & 110 \\
\hline
\end{tabular}




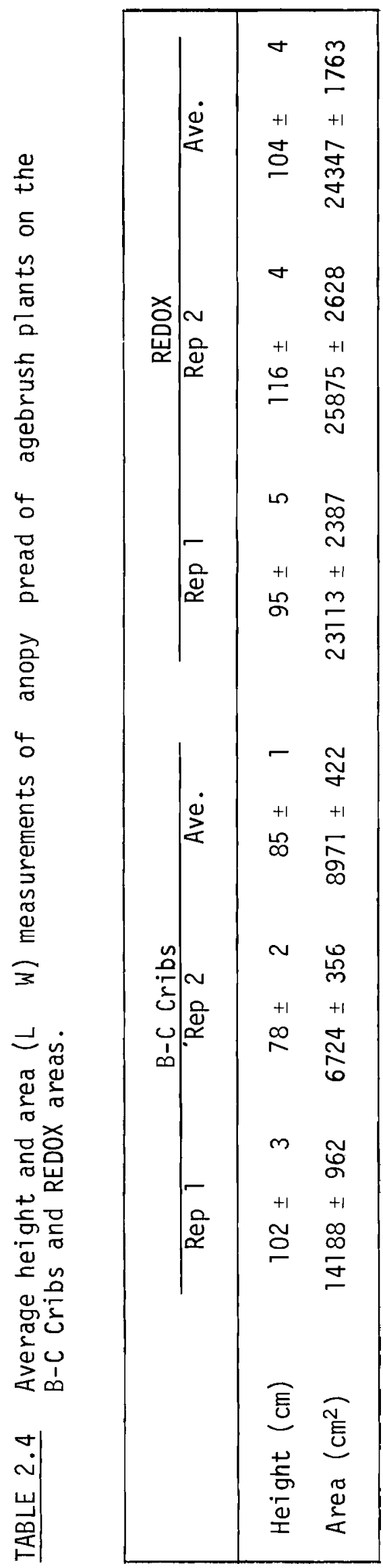




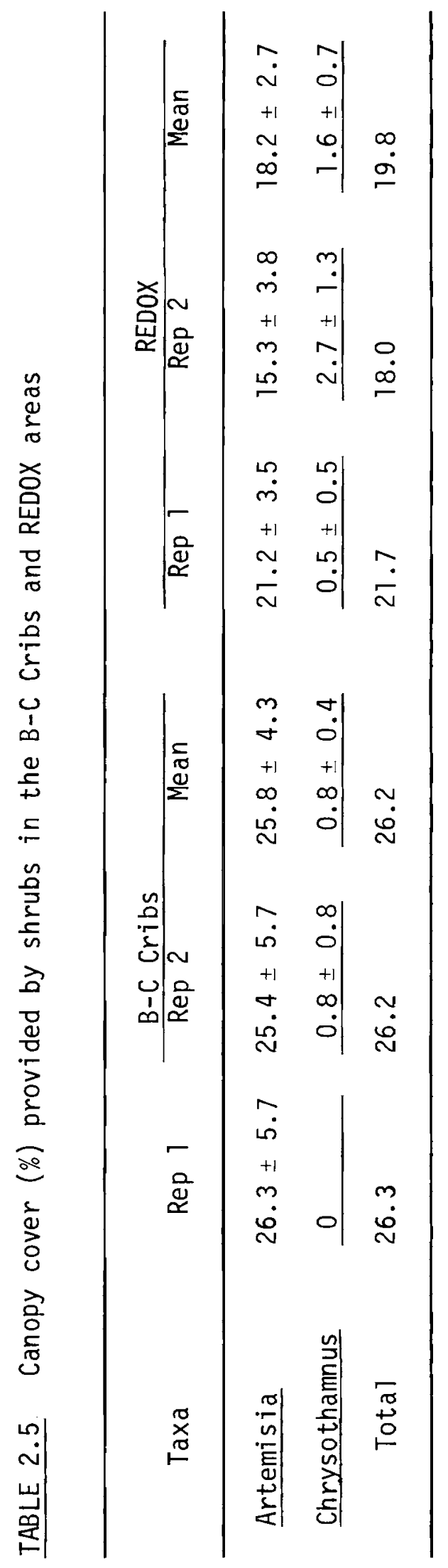


TABLE 2.6. Summary of coefficient of variations of the various parameters measured.

\section{Category}

Total understory cover

Cheatgrass cover

Total cover excluding $\underline{B}$. tectorum

Sagebrush cover $(L \times W)$

Sagebrush height

Rabbitbrush cover ( $\mathrm{L} \times \mathrm{W}$ )

Rabbitbrush height

Total shrub cover $(L \times W)$

Total shrub height
B-C Cribs

REDOX

0.59

0.69

1.11

1.00

0.66

1.03

0.91

0.67

0.33

0.31

0.64

0.95

0.33

0.44

0.90

0.76

0.33

0.38 
TABLE 2.7. Statistical comparisons of the various measurements at B-C Cribs and REDOX sites.

$\underline{\text { Measurements }}$

Cheatgrass cover

Between reps.

Transects within reps.

Total understory less cheatgrass cover

Between reps.

Transects within reps.

Total understory cover

Between reps.

Transect within Reps.

Sagebrush cover $\left(\mathrm{cm}^{2}\right)$

All shrub species cover $\left(\mathrm{cm}^{2}\right)$

Sagebrush height $\left(\mathrm{cm}^{2}\right)$

\begin{tabular}{lr}
\multicolumn{1}{c}{ Comparison } & P \\
REDOX greater than B-C Cribs & $\leq 01$ \\
No difference & .48 \\
Different & .01 \\
& \\
B-C Cribs greaterthan Redox & $\leq .01$ \\
No difference & .19 \\
Different & $\leq .001$ \\
No difference & $\geq .50$ \\
No difference & .23 \\
Different & .001 \\
REDOX greater than B-C Crib & $\leq .01$ \\
REDOX greater than B-C Crib & $\leq .01$ \\
REDOX higher than B-C Crib & $\geq .01$
\end{tabular}

01

$\leq .01$

001

.50

23

$\leq .01$

$\leq .01$

2.01 


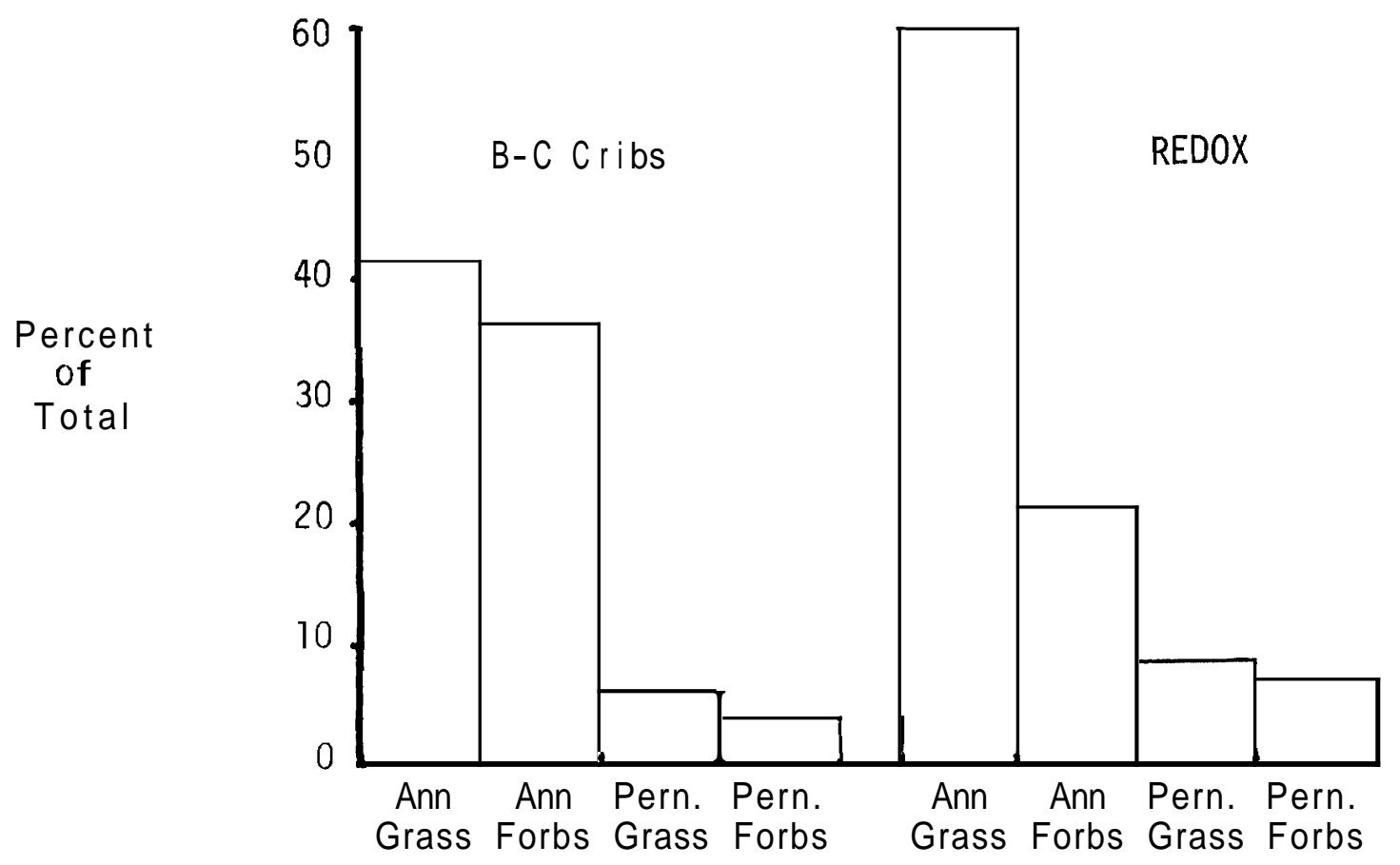

FIGURE 2.1, Distribution of canopy-cover of herbs arranged according to annual and perennial botanical categories in the B-C Cribs and REDOX areas. 
FIGURE 2.2. Shrub height distribution of live sagebrush at the B-C Cribs site.

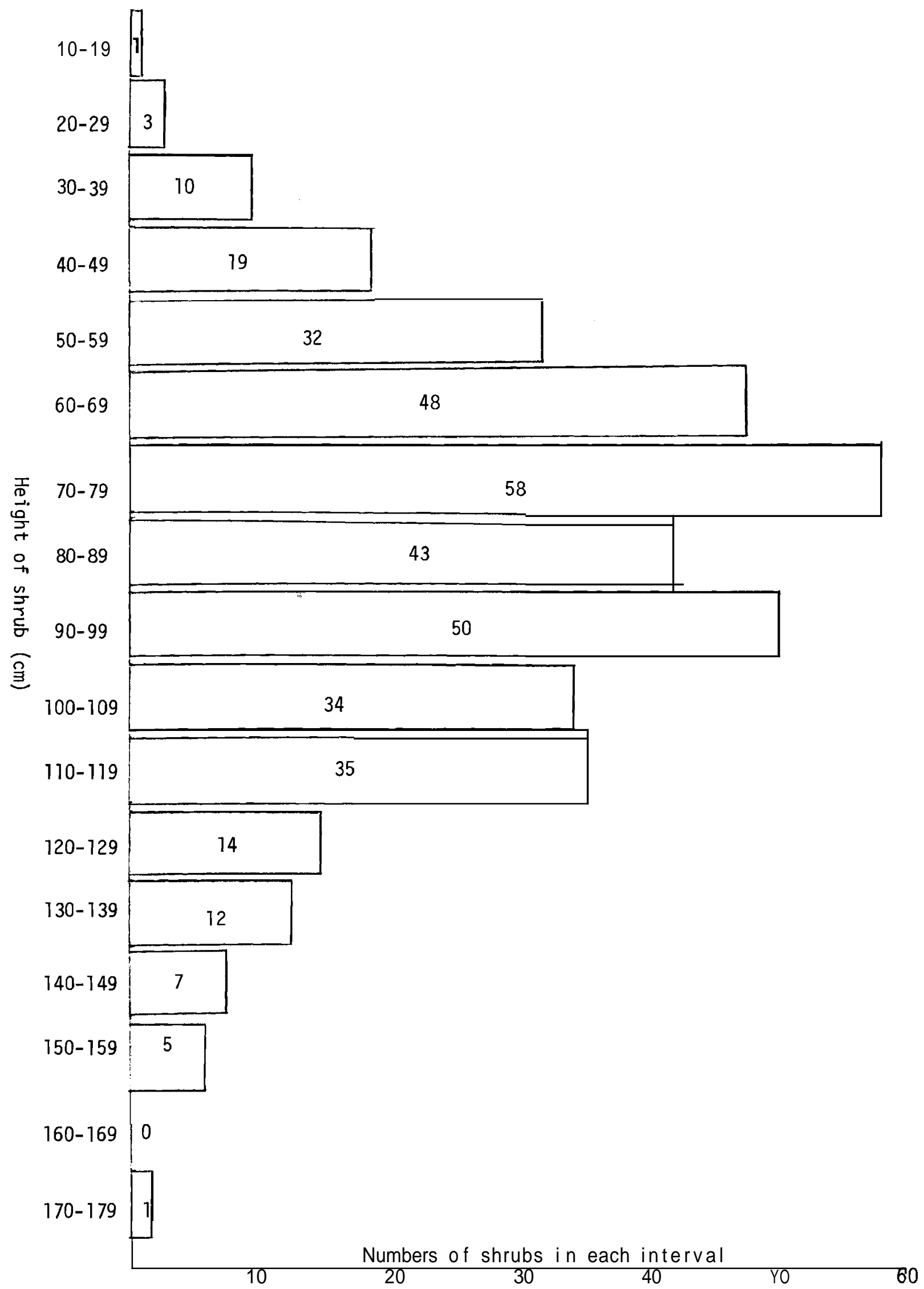


FIGURE 2.3. Shrub height distribution of live sagebrush at the REDOX site.

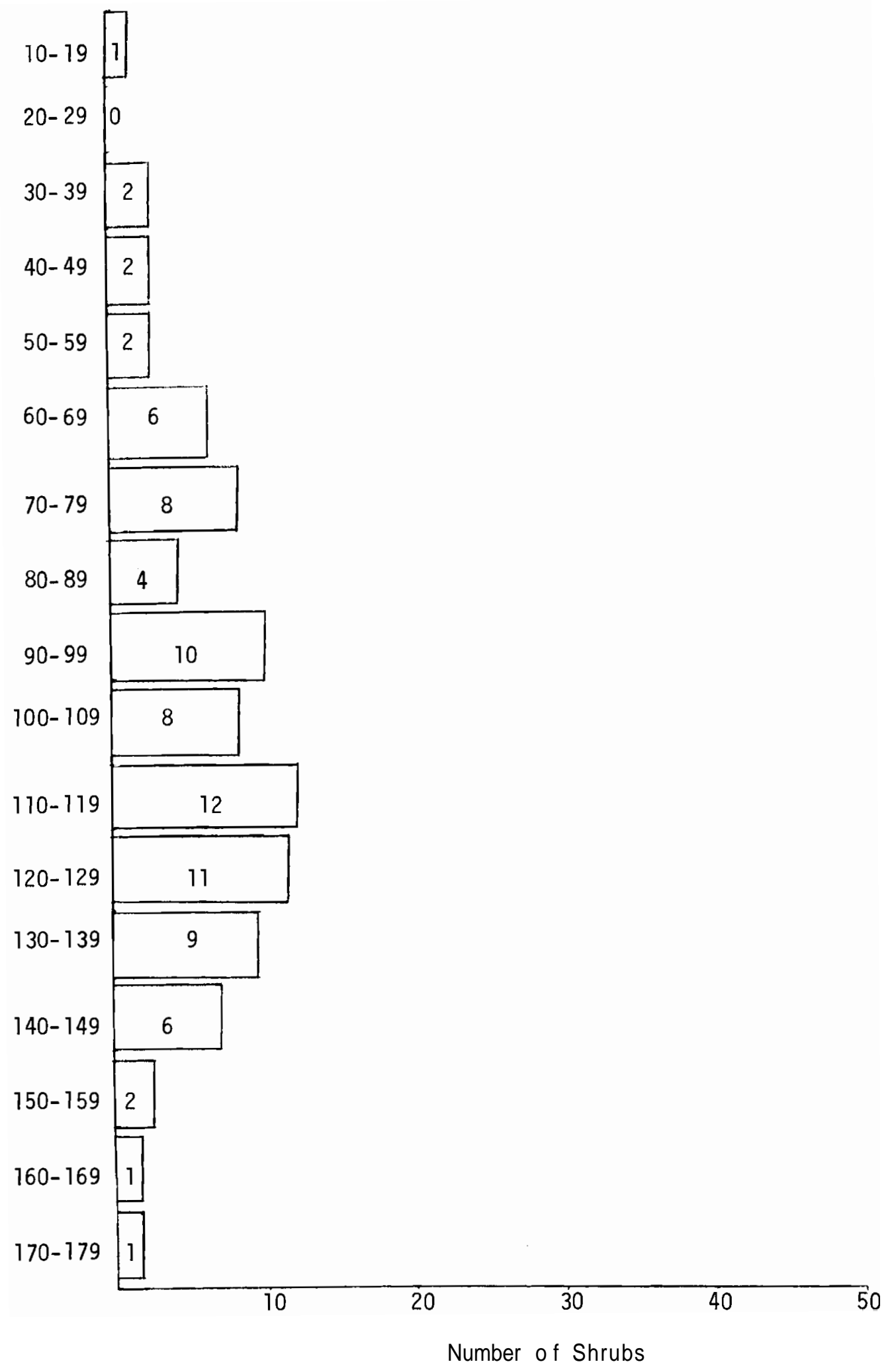




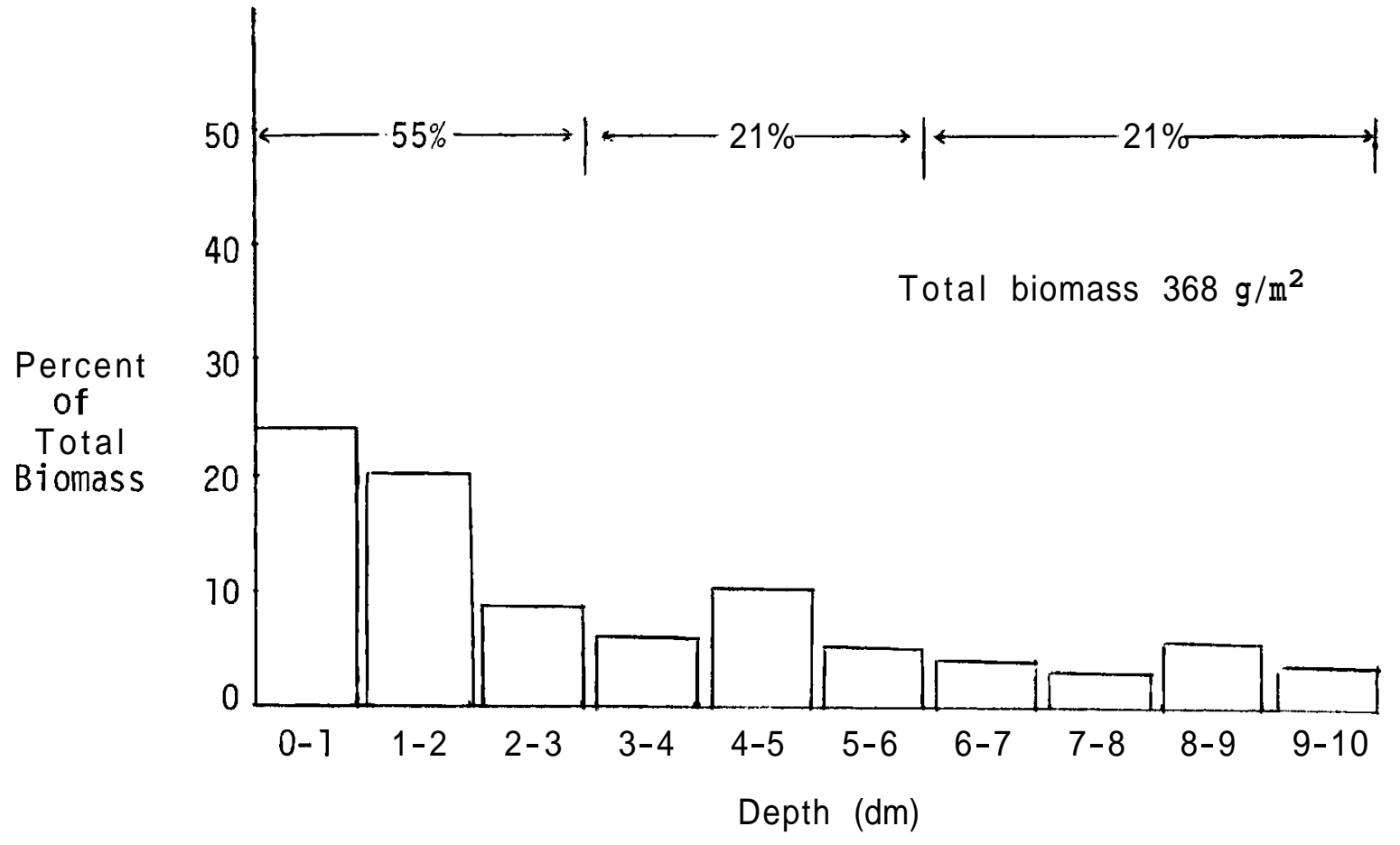

FIGURE 2.4. Distribution of belowground biomass (live + dead) in the upper meter of soil profile in a sagebrush-cheatgrass community in the B-C Cribs area. 
CHAPTER 3

\section{SOIL-PLANT RELATIONSHIPS}

Soil characteristics are extremely important interrelationships with plant and animal populations. Soi 1 provides a rooting medium and is the source of essential mineral elements and water. The soil provides a burrowing medium for mammals such as the ground squirrel, badger, pocket mouse, and for insects such as the harvester ant. Plants provide a direct source of food for herbivorous animals and shelter and nest sites for mammals and birds.

\section{SOIL PROPERT IES (PHYSICAL)}

Soil texture is important to plant growth because it determines to a large extent the water-holding capacity of a given volume of soil and also its cation exchange capacity. Soils were similar in texture, i.e., sandy loams at the B-C Cribs and REDOX sites (Table 3.1). Sand dominates the three textural classes followed by silt and clay. Clay-sized particles were scarce, making up only two percent or less of the texture size classes. These data imply that moisture-holdinq capacity of the soil profile is low and that cation exchange is also low. Also, these sandy soils are subject to serious wind erosion when disturbed. Soil types of the 200 Area plateau were mapped by Hajek (1966).

Rocks can be important considerations for plant establishment. Very stony soils, i.e., soils with a high proportion of rocks at the surface and in the profile often support plant species not found on rock-free soils. 
Although much useful information concerning the behavior and movement of ${ }^{90} \mathrm{Sr}$ and ${ }^{137} \mathrm{Cs}$ in soil has been obtained in laboratory studies using water percolation through soil columns, there are very few studies that have recorded the downward movement of radionuclides in the upper meter of soil under field conditions of moisture, temperature, and plant growth over long periods of time. One such study was conducted on the Hanford Reservation (Cline and Rickard, 1972). After 16 years of field exposure, ${ }^{90} \mathrm{Sr}$ moved downward from the soil surface to about 10 inches deep (Figure 3.1). Cesium137 moved relatively little after 8 years of field exposure (Figure 3.2). Strontium-90 was more readily available to cheatgrass than was ${ }^{137} \mathrm{Cs}$ at equivalent soil concentrations. Tansy mustard accumulated ${ }^{90} \mathrm{Sr}$ more avidly than cheatgrass. After 16 years, ${ }^{90} \mathrm{Sr}$ was still available for plant uptake.

This experiment shows that ${ }^{90} \mathrm{Sr}$ and ${ }^{137} \mathrm{Cs}$ introduced to surface soils would be vulnerable to resuspension by winds and available for uptake by cheatgrass and associated herbs for at least a century. However, it is likely that inadvertent spills of radioactive materials on soil surfaces would not be as uniformly distributed as in the experimental plots, and that the chemical forms of spilled isotopes would be substantially different from the tracer isotopes applied in the experimental study. 
TABLE 3.1. Textural analysis of the upper 0.6 meter of soil profile from the $B-C$ Cribs and REDOX areas.

\begin{tabular}{|c|c|c|c|c|c|c|}
\hline \multirow{2}{*}{$\begin{array}{c}\text { Soi } 1 \\
\text { Depth (dm) }\end{array}$} & \multicolumn{3}{|c|}{ B-C Cribs } & \multicolumn{3}{|c|}{ REDOX } \\
\hline & $\%$ Sand & $\% \mathrm{Silt}$ & $\%$ Clay & $\%$ Sand & $\% \mathrm{Si} \mid \mathrm{t}$ & $\%$ Clay \\
\hline $0-1$ & 55 & 43 & 2 & 63 & 36 & 1 \\
\hline $1-2$ & 64 & 35 & 1 & 60 & 38 & 2 \\
\hline $2-3$ & 71 & 28 & 1 & 62 & 37 & 1 \\
\hline $3-4$ & 68 & 31 & 1 & 57 & 42 & 1 \\
\hline $4-5$ & 55 & 44 & 1 & 58 & 41 & 1 \\
\hline $5-6$ & 51 & 47 & 2 & 62 & 37 & 1 \\
\hline
\end{tabular}


Sometimes layers of cobbles and gravels are found at shallow depths, mantled by fine-textured soil. These layers can impede moisture percolation and may provide physical barriers to root growth. If the proportion of rock to fine-textured soil is large, moisture distribution in the soil profile is likely to be deeper than in adjacent non-stony soils. Soils in the B-C Cribs and REDOX communities studied were essentially stone-free in the upper ane meter, a desirable feature if the soils were to be used in revegetation of the area.

Wind is an important environmental stress at the B-C and REDOX areas. Shrubs tend to alter wind speed near the ground and resuspended soi 1 tends to be deposited in the vicinity of shrubs. Deflation of soil occurs between shrubs, thereby yielding a hummocky appearance to the general ground level. The existing vegetation plays an important role in keeping wind erosion of soil surfaces to acceptable levels.

\section{SOIL PROPERT IES (CHEMICAL)}

The $\mathrm{pH}$ values of surface soils are alkaline, and alkalinity increases with profile depth (Table 3.2). Soluble salts are low, indicating that salinity (excess salts) is not a hinderance to plant growth, at least in the upper soil zones. Organic matter is low, indicative of low nitrogen levels.

Calcium dominated the soil macronutrients, followed in abundance by potassium, magnesium, phosphorus, and sulfur (Table 3.3). Calcium and magnesium concentrations tended to increase with soil depth and potassium tended to decrease. 
MINERAL CONTENT OF PLANTS

The concentrations of macronutrients in the tissues of three grass and four forb species are shown in Table 3.4. On the averaqe, macronutrient content was greater in forbs than in grasses. This is particularly evident in calcium content. Nitrogen content was nearly the same in forbs and grasses. The potassium content of tissues was greater than either magnesium or phosphorus and these, in turn, were better represented than sulfur or sodium. Sodium was sparsely represented. The concentratinns of $\mathrm{Fe}, \mathrm{Mn}, \mathrm{B}, \mathrm{Cu}$, and $\mathrm{Zn}$ are shown in Table 3.5. There were no consistent differences between grasses and forbs. Althouqh small quantities of these micronutrients are essential to the qrowth of plants, large amounts can be deleterious or toxic to plant growth.

Wallace and Romney (1972) state that the levels of calcium uptake vary among different species of desert plants. Grasses had the lowest content and forbs the highest, which is similar to our data.

Feed analyses in Table 3.6 show that the percent crude protein, crude fat, crude fiber, and ash compare with standard content in immature cheatgrass (NRC, 1969). There are no domestic animals in the area, but the analyses yield nutritional values that are potentially available to the wild herbivores such as black-tailed hares.

RADIONUCLIDE AVAILABILITY - IN SURFACE SOILS

Strontium-90 and ${ }^{137} \mathrm{Cs}$ are present in rad-wastes and are important in terrestrial ecosystems. These are readily assimilated into the tissues of plants and animals and have physical half-times persistent enough to allow participation in mineral cycling behavior. 
TABLE 3.2. Organic matter (\%), pH, and soluble salts (mmhos $/ \mathrm{cm}$ ) in the upper 0.6 meters of soil profile in the B-C Cribs and REDOX areas.

\begin{tabular}{|cccccccc|}
\hline \multirow{2}{*}{$\begin{array}{c}\text { Soi } 1 \\
\text { Depth (dm) }\end{array}$} & \multicolumn{3}{c}{ B-C Cribs } & \multicolumn{3}{c|}{ REDOX } \\
\cline { 2 - 5 } \cline { 6 - 8 } & Org. Mat. & pH & Sol. Salt & & Org. Mat. & pH & Sol. Salt \\
$1-1$ & .65 & 7.5 & .27 & .70 & 7.5 & .23 \\
$2-3$ & .45 & 7.4 & .23 & .45 & 7.8 & .16 \\
$3-4$ & .25 & 7.5 & .30 & .45 & 7.9 & .18 \\
$4-5$ & .35 & 7.7 & .40 & .50 & 8.0 & .18 \\
$5-6$ & .30 & 7.8 & .20 & .55 & 8.0 & .21 \\
\hline
\end{tabular}


TABLE 3.3. Macronutrients (ppm) in the upper 0.6 meter of soil profile in the B-C Cribs and REDOX areas.

\begin{tabular}{|c|c|c|c|c|c|c|c|c|c|c|}
\hline \multirow{2}{*}{$\begin{array}{c}\text { Soi } 1 \\
\text { Depth (dm) }\end{array}$} & \multicolumn{5}{|c|}{ B-C Cribs } & \multicolumn{5}{|c|}{ REDOX } \\
\hline & $P$ & K & $S$ & $\mathrm{Ca}$ & $\mathrm{Mg}$ & $\bar{P}$ & $\mathrm{~K}$ & $S$ & $\mathrm{Ca}$ & $7 \mathrm{Mg}$ \\
\hline $0-1$ & 9 & 214 & 1 & 720 & 102 & 10 & 250 & 1.5 & 760 & 126 \\
\hline $1-2$ & 13 & 219 & 1 & 720 & 114 & 7 & 260 & 1.0 & 880 & 150 \\
\hline $2-3$ & 8 & 198 & 1 & 800 & 132 & 5 & 260 & 1.0 & 1070 & 192 \\
\hline $3-4$ & 4 & 165 & 1 & 800 & 138 & 6 & 205 & 1.0 & 1100 & 204 \\
\hline $4-5$ & 3 & 120 & 1 & 810 & 132 & 4 & 180 & 1.5 & 1790 & 222 \\
\hline $5-6$ & 3 & 115 & 1 & 2200 & 156 & 4 & 185 & 1.5 & 3000 & 288 \\
\hline
\end{tabular}


TABLE 3.4. Macronutrients in herbaceous plant taxa from B-C Cribs area.

\begin{tabular}{|c|c|c|c|c|c|c|c|}
\hline \multirow[b]{2}{*}{ Taxa } & \multicolumn{7}{|c|}{ Macronutrients \% dry wt. } \\
\hline & $\mathrm{N}$ & $P$ & $\mathrm{~K}$ & $\mathrm{Ca}$ & $\mathrm{Mg}$ & N & $\bar{S}$ \\
\hline \multicolumn{8}{|l|}{ Grasses } \\
\hline Bromus tectorum & 0.92 & 0.17 & 1.17 & 0.43 & 0.16 & 0.03 & 0.10 \\
\hline$\underline{\text { Festuca octoflora }}$ & 0.93 & 0.14 & 0.66 & 0.40 & 0.13 & 0.02 & 0.14 \\
\hline Poa sandbergii & 117 & 0.18 & 0.75 & 040 & 012 & 0.05 & 013 \\
\hline Average & 1.01 & 0.16 & 0.86 & 0.41 & 0.14 & 0.03 & 0.12 \\
\hline \multicolumn{8}{|l|}{ Forbs } \\
\hline$\underline{\text { Descurainia pinnata }}$ & 1.34 & 0.29 & 1.13 & 1.16 & 0.26 & 0.04 & 0.31 \\
\hline Mcrosteris gracilis & 0.71 & 0.19 & 0.88 & 1.49 & 0.27 & 0.08 & 0.14 \\
\hline Cryptantha circumscissa & 1.13 & 0.38 & 1.08 & 5.40 & 0.41 & 0.06 & 0.13 \\
\hline Cryptantha pterocarya & 1.09 & 0.14 & 2.14 & 1.73 & 0.17 & 0.05 & 0.12 \\
\hline Average & 1.06 & 0.25 & 1.30 & 2.44 & 0.28 & 0.06 & 0.17 \\
\hline
\end{tabular}


TABLE 3.5. Micronutrients in herbaceous plant taxa from the B-C Cribs area.

\begin{tabular}{|c|c|c|c|c|c|}
\hline \multirow[b]{2}{*}{ Taxa } & \multicolumn{5}{|c|}{ Micronutrients \% dry wt. } \\
\hline & $\mathrm{Fe}$ & $\mathrm{Mh}$ & $\mathrm{B}$ & $\mathrm{Cu}$ & $\mathrm{Zn}$ \\
\hline \multicolumn{6}{|l|}{ Grasses } \\
\hline Bromus tectorum & .04 & .004 & .001 & .0003 & .001 \\
\hline Festuca octof1ora & .04 & .006 & .002 & .0002 & .002 \\
\hline Poa sandbergii & .05 & .004 & .002 & .0003 & .001 \\
\hline Average & .04 & .005 & .002 & .0003 & .001 \\
\hline \multicolumn{6}{|l|}{ Forbs } \\
\hline Descurainia pinnata & .03 & .002 & .003 & .0005 & .002 \\
\hline Microsteris gracilis & .21 & .006 & .003 & .0004 & .002 \\
\hline Cryptantha circumscissa & .13 & .007 & .006 & .0004 & .002 \\
\hline Cryptantha pterocarya & 06 & .005 & .005 & .0003 & .001 \\
\hline Average & - I I & .005 & .004 & .0004 & .002 \\
\hline
\end{tabular}


TABLE 3.6. Feed analysis of herbaceous plant taxa from the B-C Cribs area.

\begin{tabular}{|lcccc|}
\hline \multicolumn{1}{|c|}{ Taxa } & \multicolumn{5}{c|}{ Percent } \\
\cline { 2 - 5 } & Protein & Crude Fat & Crude Fiber & Ash \\
\hline Grasses & & & 31.9 & 8.7 \\
Bromus tectorum & 5.7 & 1.8 & 29.4 & 9.6 \\
Festuca octof7ora & 5.9 & 1.9 & 30.9 & 9.1 \\
Poa sandbergi i & 6.9 & 2.2 & & \\
Forbs & & & 35.4 & 5.7 \\
$\frac{\text { Descurainia pinnata }}{\text { Microsteris graci7is }}$ & 4.5 & 2.5 & 26.6 & 19.6 \\
$\frac{\text { Cryptantha circumscissa }}{\text { Cryptantha pterocarya }}$ & 7.1 & 1.6 & 17.0 & 34.0 \\
\hline
\end{tabular}




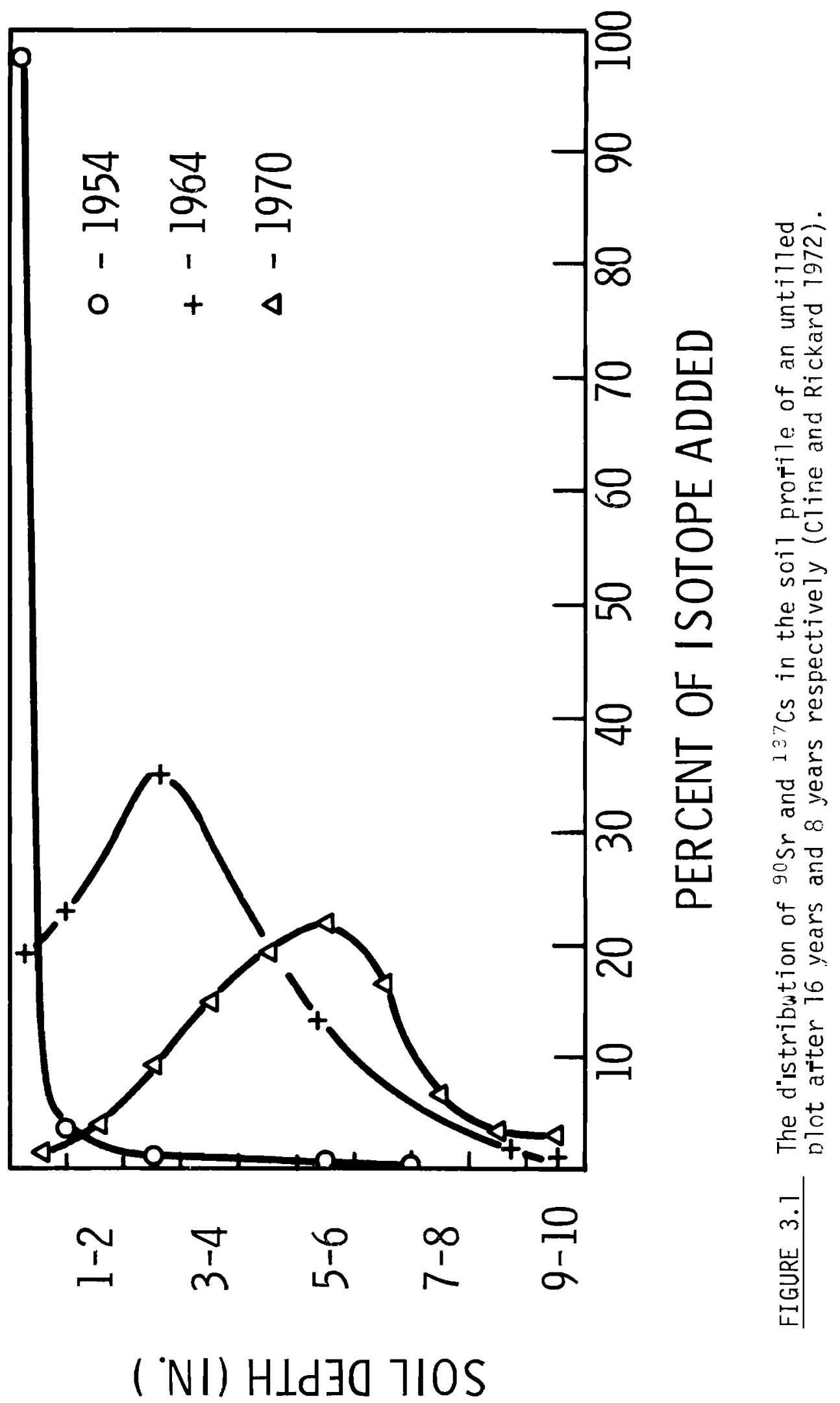




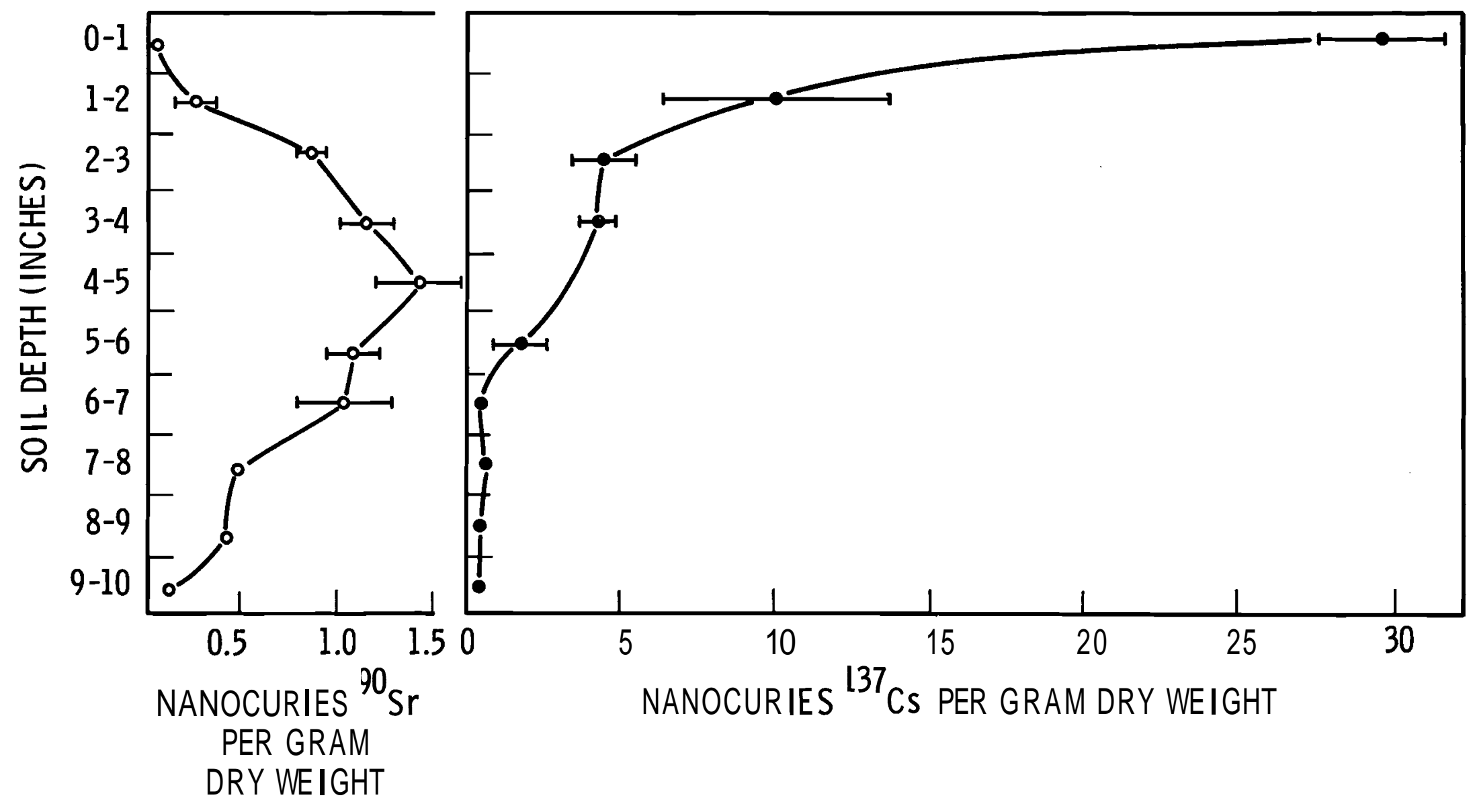

FIGURE 3.2. The distribution of ${ }^{30} \mathrm{Sr}$ and ${ }^{137} \mathrm{CS}$ in the soil profile in tilled plots after 16 and 8 years, respectively. 


\section{LITERATURE CITED}

Beatley, J. C. 1969. Biomass of desert winter annual populations in southern Nevada. Oikos 20:261-273.

Cline, J. F. and W. H. Rickard. 1972. Radioactive strontium and cesium in cultivated field plots. Health Phys. 23:317-324.

Cline, J. F. and W. H. Rickard. 1973. Herbage yields in relation to soil water and assimilated nitrogen. J. Range Mgt. 26:296-298.

Daubenmire, R. 1959. A canopy-coverage method of vegetation analysis. Northwest Sci. 33:43-64.

Daubenmi re, R. 1970. Steppe vegetation of Washington. Wash. Agr. Exp. Station Tech. Bull. 62:131.

Hajek, B. F. 1966. Soil Survey - Hanford Project in Benton County, Washington, BNWL-243, Battelle-Northwest, Richland, WA

Hitchcock, C. L. and A. Cronquist. 1973. Flora of the Pacific Northwest. Univ. of Wash. Press, Seattle and London. P. 730.

Hyder, D. N., R. E. Bement, E. E. Remnenga, and C. Terwillinger, Jr. 1966. Vegetation-soils and vegetation-grazing relations from frequency data. J. Range Mgt. 19:11-17.

Miller, R. G., Jr. 1966. Simultaneous Statistical Inference. McGrawHill Book Co., New York, NY. P. 272.

National Research Counci 1 and Dept. of Agr., Canada. 1969. Nutritional data for United States and Canadian feeds, 2nd rev. United States Canadian Tables of Feed Composition: 1684. Nat. Acad. Sci., Washington, D.C. $92 \mathrm{pp}$. 
Price, K. R., and W. H. Rickard. 1972. Botanical description of the AEC-IBP grassland biome study site, pp 3.2-3.3. In: Pacific Northwest Laboratory Annual Report for 1971. BNWL-1650, Vol. 1, Part 2, Battelle-Northwest, Richland, WA

Rickard, W. H., and J. C. Beatley. 1965. Canopy-coverage of the desert shrub vegetation mosaic of Nevada Test site. Ecology 46:524-529. Rickard, W. H. 1970. The distribution of ground-dwelling beetles in relation to vegetation, season and topography in the Rattlesnake Hills, southeastern Washington. Northwest Sci. 44:107-113.

Rickard, W. H., and J. F. Cline. 1971. Germination of seeds from soil in burned and unburned sagebrush-bitterbrush vegetation, pp 1.51.6. In: Pacific Northwest Laboratory Annual Report for 1970, BNWL-1550, Vol. 1, Part 2, Battelle-Northwest, Richland, WA.

Rickard, W. H. 1974. Vegetation of knob and kettle topography in south-central Washington (manuscript).

St. John, J. and G. N. Jones. 1928. An annotated catalogue of vascular plants of Benton County, Washington. Northwest Sci. 2:73-93.

Snedecor, G. W., and W. G. Cochran. 1967. Statistical Methods. Iowa State University Press, Ames. PP 115-116.

Stone, W. A., D. E. Jenne, and J. M. Thorp. 1972. Climatography of the Hanford Area, BNWL-1605, Battelle-Northwest, Richland, WA

Wallace, A and E. M. Romney. 1972. Radioecology and Ecophysiology of Desert Plants at the Nevada Test Site, TID-25954, Environmental RAd. Div., Lab of Nuclear Med. and Rad. Bio. and Agr. Sci., Los Angeles Soil Sci. and Agr. Eng., Riverside Univ. of Calif., U.S. Energy Research and Development Administration's Office of Information Services, pp 69-72. 
APPENDIX 
APPENDIX 1. Preliminary species list of plants occurring within the REDOX area and B-C sites.

Common Name

$\underline{\text { Scientific Name }}$

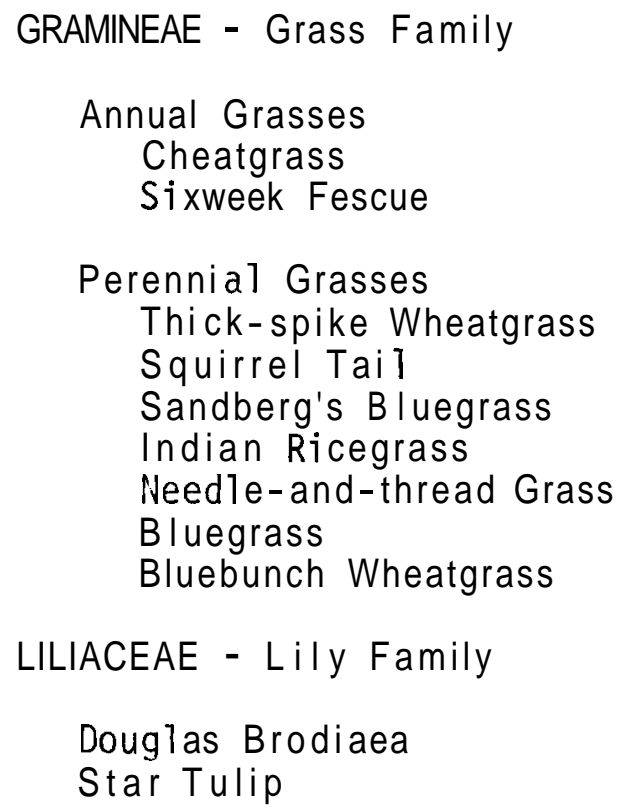

Brodiaea douglasii

Calochortus macrocarpus

SANTALACEAE - Sandalwood Family

Comandra

Bromus tectorum Festuca octoflora

Agropyron dasytachyum

Sitanion hystrix

Poa sandberqi i

Oryzopsis hymenoides

Stipa comata

Poa canbyi

Agropyron spicatum

POLYGONACEAE - Buckwheat Family

Buckwheat

Eriogonum sp.

CHENOPODIACEAE - Goosefoot Family

Russian Thistle

Salsola kali

Hopsage

Comandra pallida

CRUCIFERAE - Mustard Family

Tansy Mustard

Western Wallflower

Jim Hill Mustard

Draba Grayia spinosa

LEGUMINOSAE - Pea Family

Locoweed

Spurred Lupine

Scurf-pea

Descurainia pinnata

Erysimum asperum

Sisymbrium altissimum

Draba verna

Astraqalus sp.

Lupinus $\mathrm{sp}$.

Psoralea lanceolata 
Common Name

GERANIACEAE - Geranium Famil y

Storks-bi 11

LAOSACEAE - Loasa Family

White Stem Mentzelia

ONAGRACEAE - Evening Primrose Family

Evening Primrose

UMBELLIFERAE - Parsley Family

Turpentine Cymopterus

POLEMONIACEAE - Phlox Family

Long-leaved Phlox

Microsteris

HYDROPHYLLACEAE - Waterleaf Family

Narrow-1eaved Phacel is

BORAGINACEAE - Borage Family

Fiddl eneck

Matted Cryptantha

Wing-nut Cryptantha

SCROPHULARIACEAE - Fi gwort Family

Sharp-leaved Penstemon

COMPOSITAE - Sunflower Family

Big Sagebrush

Rabbit Brush

Rabbit Brush

Bur Sage

Balsamroot

Yarrow

Aster species

Erigeron species
Scientific Name

Erodium cicutarium

Mentzelia albicaulis

Oenothera pal 1ida

Cymopterus terebinthinus

Phlox longifolia

Microsteris gracilis

Phacelis Tinearis

Amsinckia 1ycopsoides

Cryptantha circumscissa

$\underline{\text { Cryptantha pterocarya }}$

Penstemon acuminatus

Artemisia tridentata Chrysotharnnus nauseosus Chrysothamnus viscidiflorus Franseria acanthicarpa

Balsamorhiza careyana

Achillea lanulosa

Aster sp.

Erigeron $s p$. 


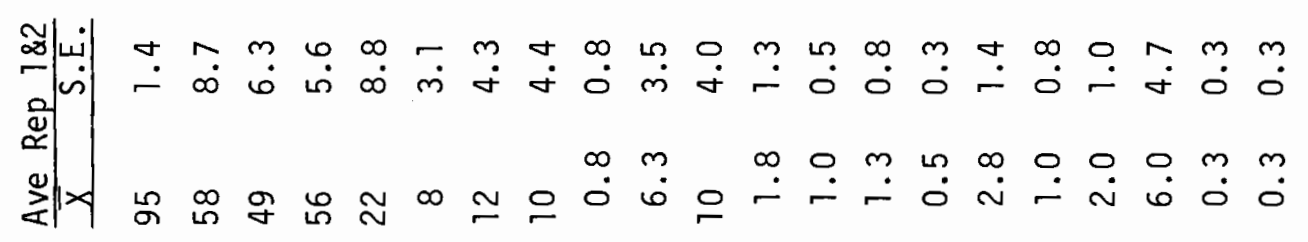

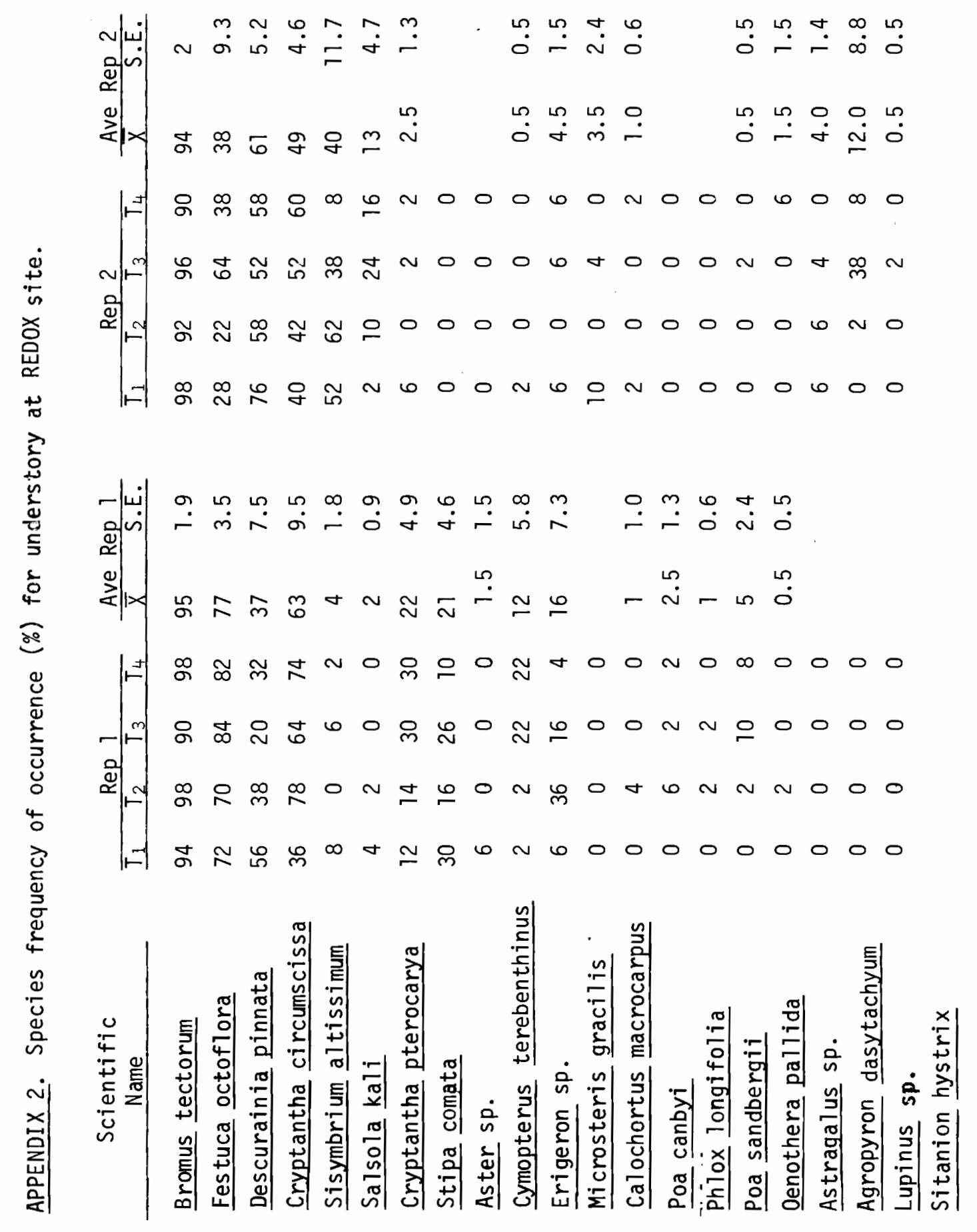




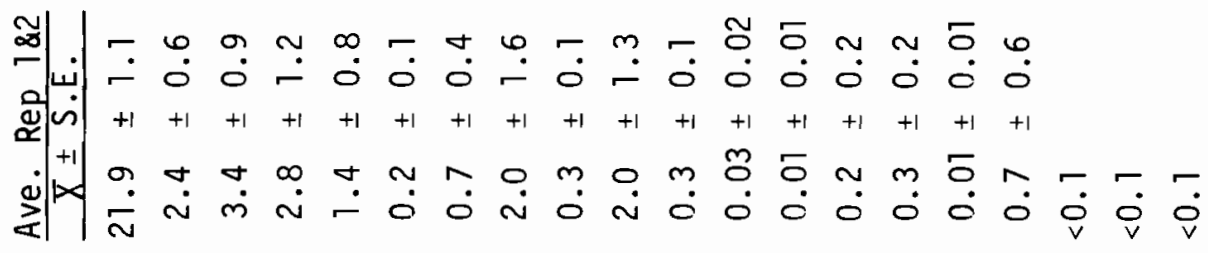

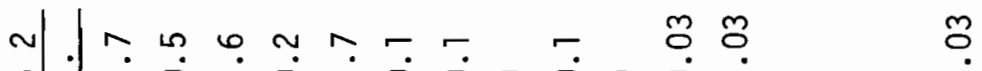

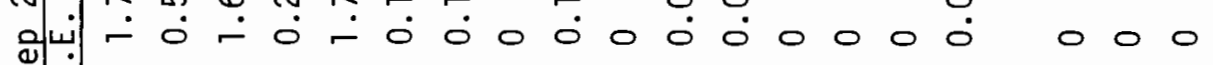

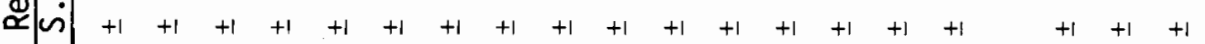

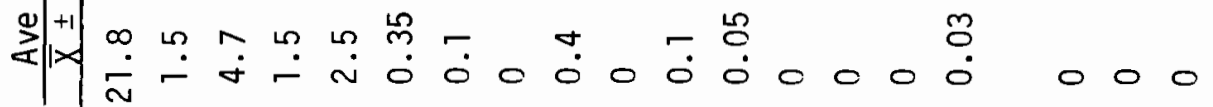

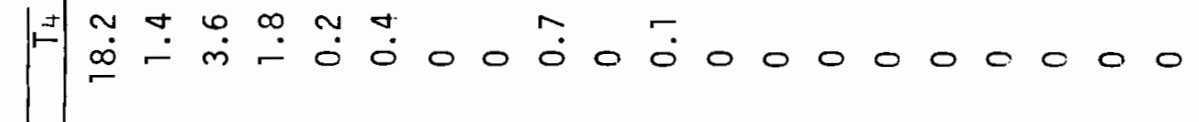

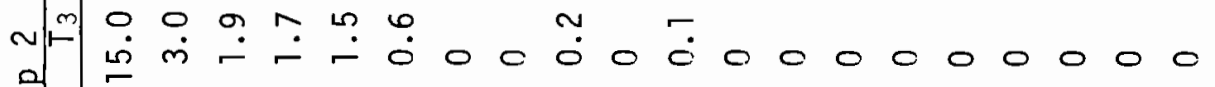

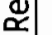

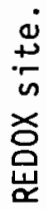

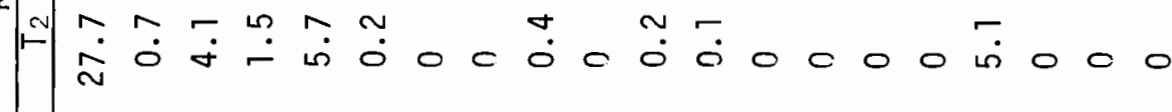

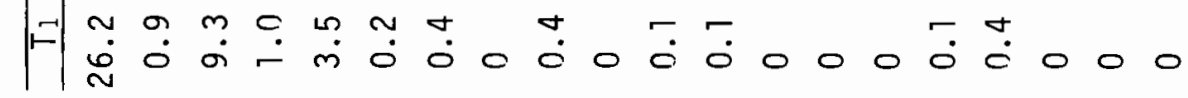

$-\mid$ ln a $m \sim-\widetilde{O} \sim \sim--\sim \%$

前

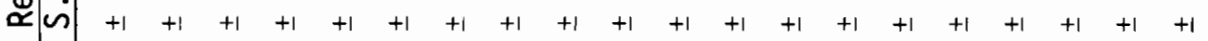

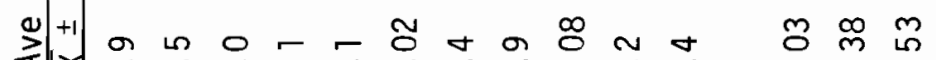

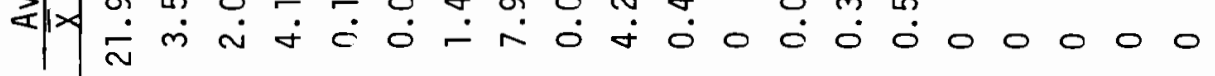

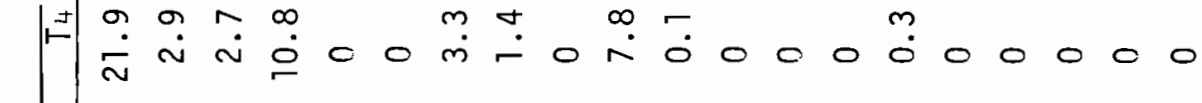

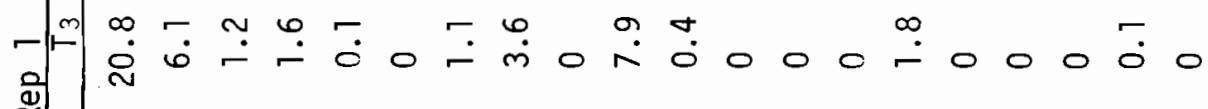
बे.

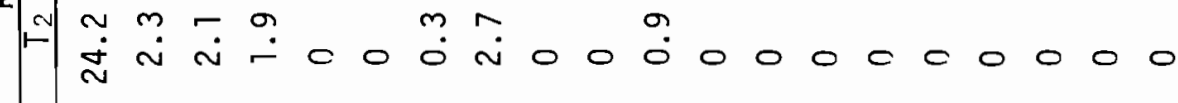

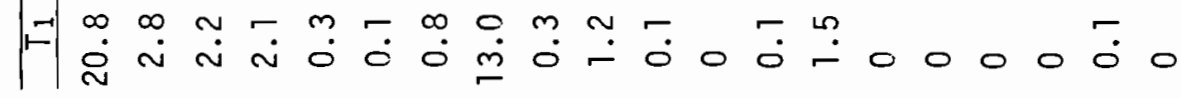

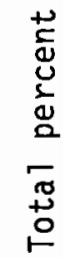

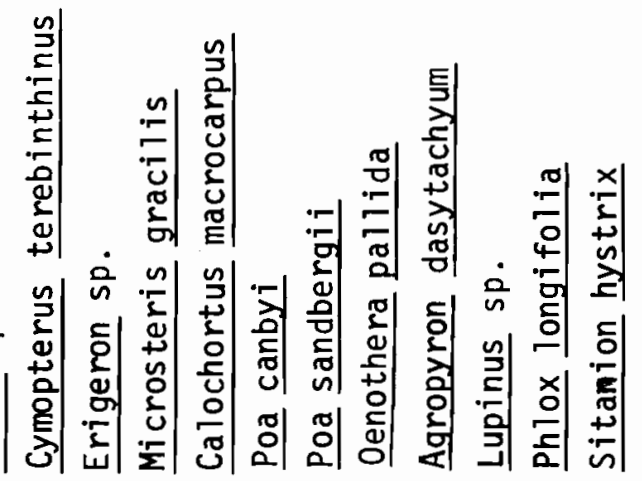




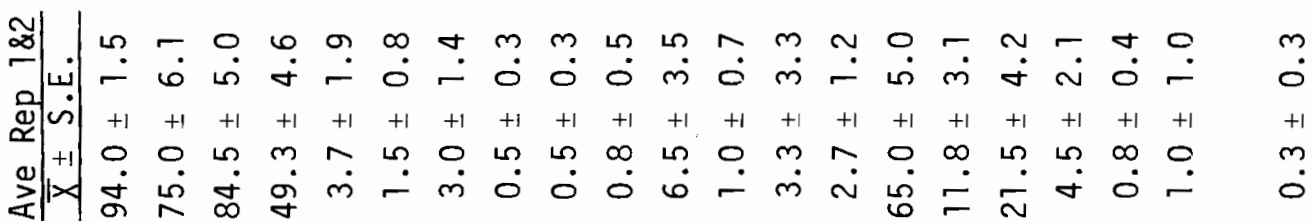

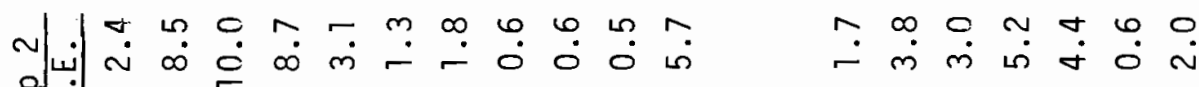



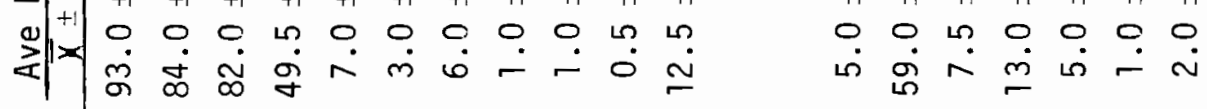

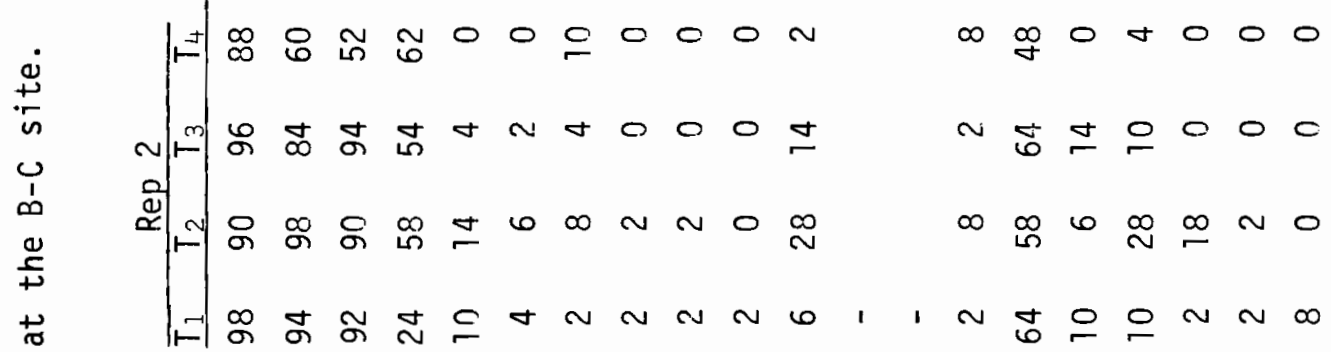

זे

气ั

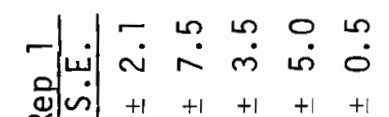

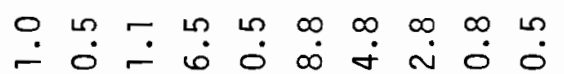

$\stackrel{10}{0}$

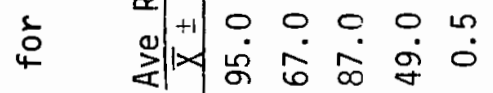

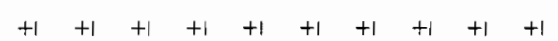

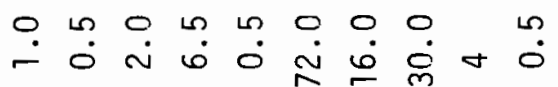

$+1$

29

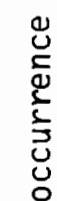

4

రิ $\mid$

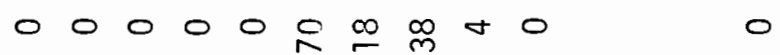

|게

$000000 N \underset{N}{N}$

0

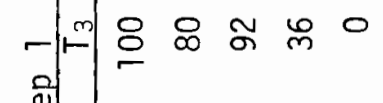

O

o

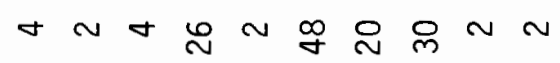

$\sim$

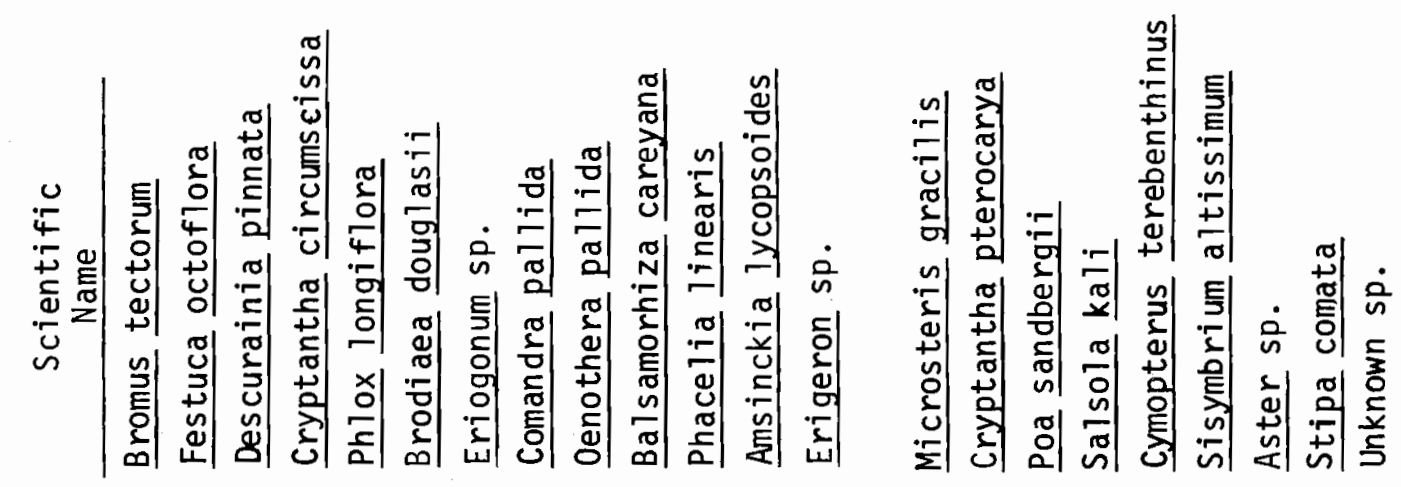




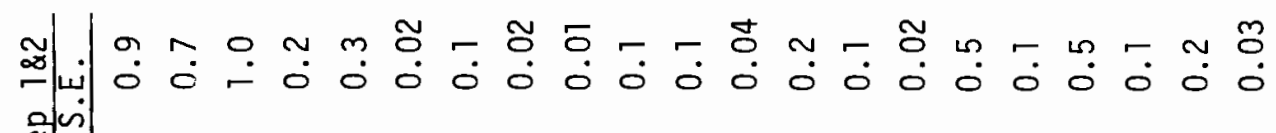

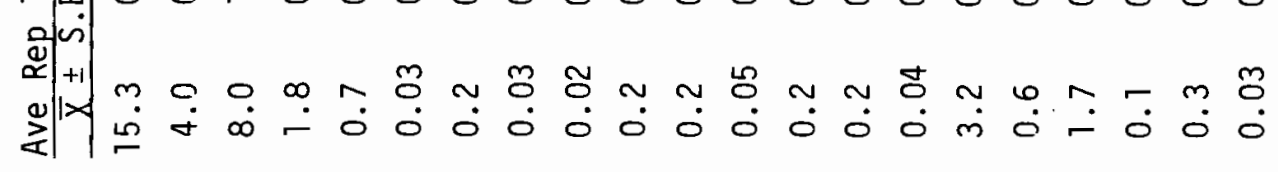

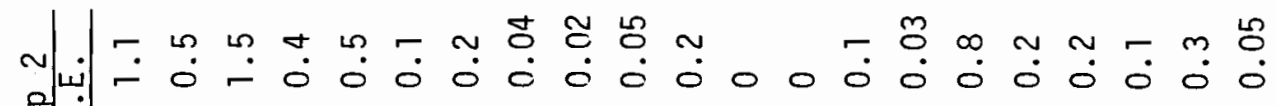
원

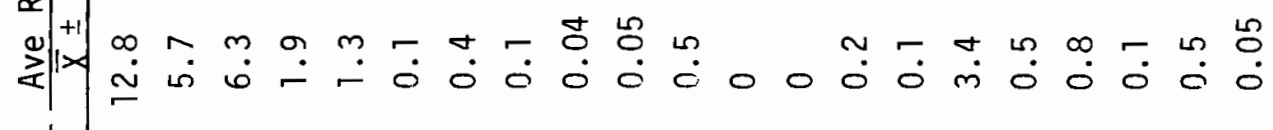

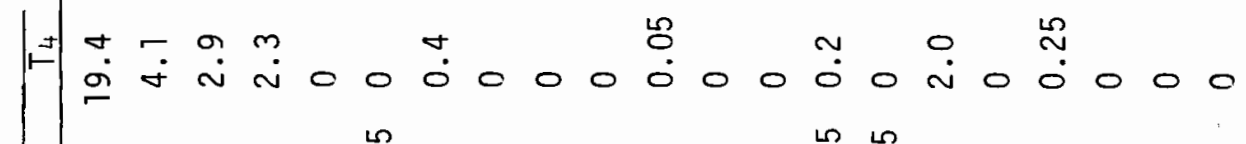

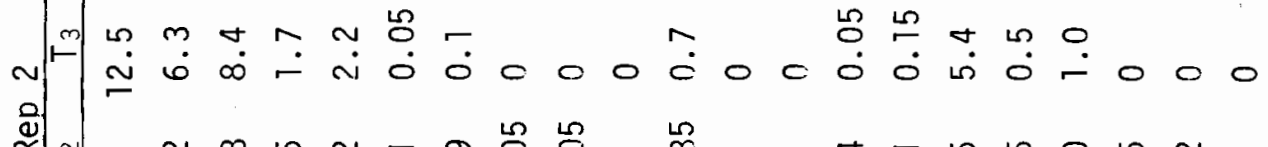

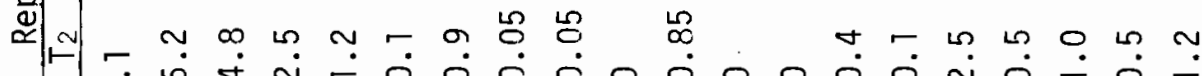

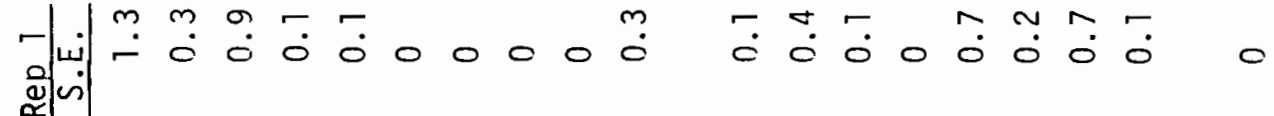

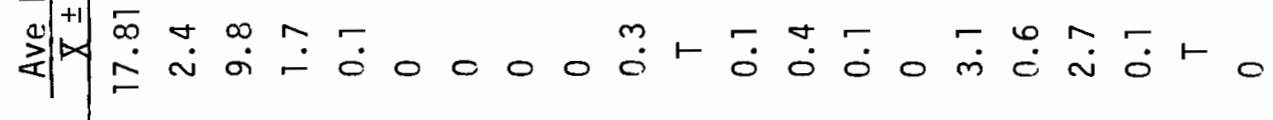

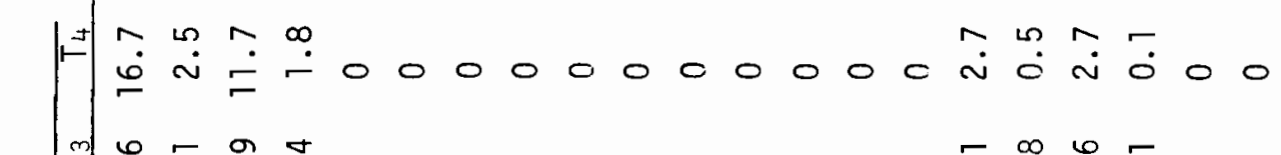
岗|

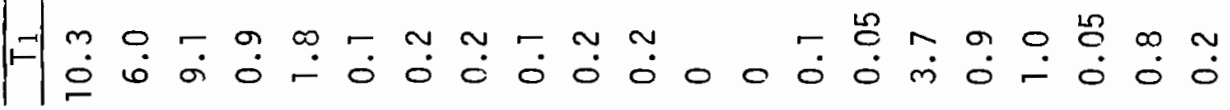

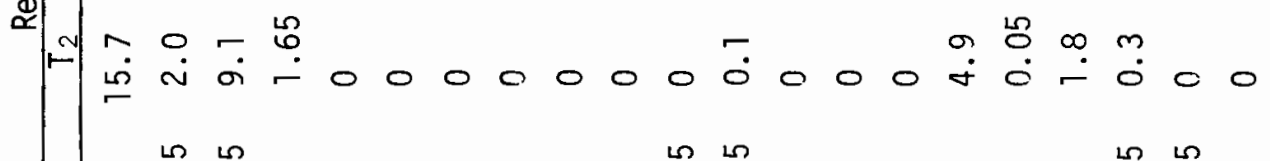

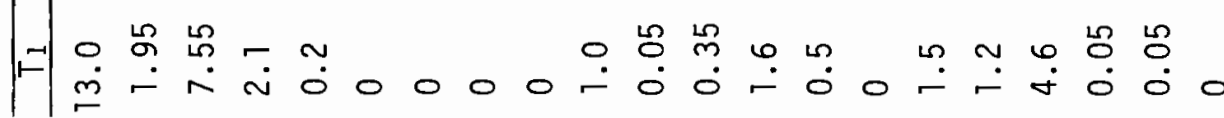


APPENDIX 6. Comparison of percent cheatgrass cover at B-C and REDOX sites.

\begin{tabular}{|c|c|c|c|c|c|c|}
\hline & & & REDOX & & & \\
\hline & & Rep 1 & & & Rep 2 & \\
\hline & $n$ & $\bar{X} \pm S . E$. & C.V. & $n$ & $\vec{X} \pm$ S.E. & C.V. \\
\hline$T_{1}$ & 50 & $20.8 \pm 2.9$ & 1.00 & 50 & $26.2 \pm 3.9$ & 1.04 \\
\hline $\mathrm{T}_{2}$ & 50 & $24.2 \pm 2.9$ & 0.84 & 50 & $27.8 \pm 3.4$ & 0.87 \\
\hline $\mathrm{T}_{3}$ & 50 & $20.8 \pm 3.0$ & 1.02 & 50 & $15.0 \pm 2.5$ & 1.18 \\
\hline$T_{4}$ & 50 & $21.9 \pm 3.2$ & 0.98 & 50 & $\underline{18.2} \pm \underline{3.1}$ & 1.20 \\
\hline & 200 & $21.9 \pm 1.5$ & 0.97 & 200 & $21.8 \pm 1.7$ & 1.10 \\
\hline & & & Ave. $R 1+R 2$ & 400 & $21.9 \pm 1.1$ & 1.00 \\
\hline & & & B-C Crib & & & \\
\hline & & Rep 1 & & & $\operatorname{Rep} 2$ & \\
\hline & $n$ & $\bar{X} \pm S . E$. & C.V. & $n$ & $\bar{X} \pm$ S.E. & C.V. \\
\hline$T_{1}$ & 50 & $13.0 \pm 2.1$ & 1.12 & 50 & $10.2 \pm 1.4$ & 0.99 \\
\hline$T_{2}$ & 50 & $15.6 \pm 2.3$ & 1.07 & 50 & $9.1 \pm 1.7$ & 1.30 \\
\hline$T_{3}$ & 50 & $25.9 \pm 3.2$ & 0.87 & 50 & $12.5 \pm 1.9$ & 1.08 \\
\hline$T_{4}$ & 50 & $16.7 \pm 2.3$ & 0.98 & $\underline{50}$ & $19.4 \pm 2.9$ & 1.08 \\
\hline & 200 & $17.8 \pm 1.3$ & 1.03 & 200 & $12.8 \pm 1.1$ & 1.20 \\
\hline & & & Ave. R1+ & 400 & $15.3 \pm 0.9$ & 1.11 \\
\hline
\end{tabular}

Statistical Comparisons:

Cover at REDOX higher than B-C Crib $p \leq .01$

No difference between reps $\quad p=.48$

Transects different within reps $\quad p=.01$ 
APPEIIDIX 7. Comparison of total understory cover excluding cheatgrass at B-C and REDOX sites.

\begin{tabular}{|c|c|c|c|c|c|}
\hline \multicolumn{6}{|c|}{ REDOX } \\
\hline \multicolumn{3}{|c|}{ Rep 1} & \multicolumn{3}{|c|}{ Rep 2} \\
\hline$n$ & $\bar{X} \pm$ S.E. & C.V. & $n$ & $\bar{X} \pm S . E$. & C.V. \\
\hline 50 & $18.1 \pm 2.6$ & 1.00 & 50 & $16.1 \pm 2.7$ & 1.16 \\
\hline 50 & $12.2 \pm 2.0$ & 1.14 & 50 & $13.7 \pm 1.9$ & 1.03 \\
\hline 50 & $21.9+2.8$ & 0.91 & 50 & $9.5 \pm 0.8$ & 0.57 \\
\hline 50 & $19.4 \pm 2.7$ & $\underline{0.99}$ & 50 & $\underline{13.6} \pm \underline{1.5}$ & 0.77 \\
\hline 00 & $17.9 \pm 1.3$ & 1.02 & 200 & $13.1 \pm 0.9$ & 1.00 \\
\hline & & tye. & 400 & $15.5 \pm 0.8$ & 1.03 \\
\hline
\end{tabular}

B-C Crib

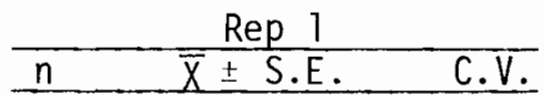

\begin{tabular}{lll} 
& Rep 2 \\
\hline$n \quad \bar{X} \pm$ S.E. & C.V. \\
\hline
\end{tabular}

$\mathrm{T}_{1}$

$50 \quad 20.2 \pm 1.9 \quad 0.64$

$50 \quad 23.4 \pm 2.1 \quad 0.64$

$T_{2}$

$50 \quad 20.3 \pm 2.2 \quad 0.75$

$50 \quad 20.5 \pm 1.6 \quad 0.53$

$\mathrm{T}_{3}$

$50 \quad 21.6 \pm 2.1 \quad 0.69$

$50 \quad 22.7 \pm 1.9 \quad 0.59$

$T_{4}$

$50 \quad \underline{22.1} \pm \underline{1.6} \quad \underline{0.53}$

$50 \quad \underline{15.8} \pm \underline{2.1} \quad \underline{0.96}$

$200 \quad 21.1 \pm 0$.

0.65

200

$20.6 \pm 1.0 \quad 0.68$

Ave. R1 + R2

400

$20.9 \pm 0.7$

0.66

Statistical Comparisons:

Cover different between sites $\quad p \leq .01$

No difference between reps

$p=.19$

Transects different within reps

$p \leq .001$ 
APPENDIX 8. Comparison of total percent understory cover at
$B-C$ and REDOX sites.

\section{REDOX}

\begin{tabular}{|c|c|c|c|c|c|}
\hline \multirow{2}{*}{\multicolumn{3}{|c|}{$\begin{array}{r}\text { Rep } 1 \\
\bar{X} \pm \text { S.E. }\end{array}$}} & \multicolumn{3}{|c|}{ Rep 2} \\
\hline & & & $n$ & $\bar{X} \pm$ S.E. & C.V. \\
\hline 50 & $38.9 \pm 3.3$ & 0.61 & 50 & $42.4 \pm 4.2$ & 0.70 \\
\hline 50 & $36.5 \pm 3.0$ & 0.58 & 50 & $40.9 \pm 3.9$ & 0.67 \\
\hline 50 & $42.8 \pm 3.8$ & 0.63 & 50 & $24.6 \pm 2.8$ & 0.79 \\
\hline 50 & $41.4 \pm 4.1$ & 0.71 & 50 & $31.8 \pm 3.3$ & 0.74 \\
\hline 0 & $39.9 \pm 1.8$ & 0.64 & 200 & $34.9 \pm 1.8$ & 0.75 \\
\hline & & ve. $R 1+R 2$ & 400 & $37.4 \pm 1.3$ & 0.69 \\
\hline
\end{tabular}

B-C Crib

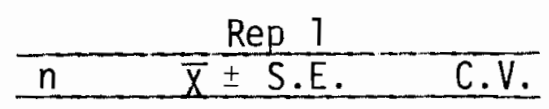

$T_{1}$

$\mathrm{T}_{2}$

$\mathrm{T}_{3}$

$\mathrm{T}_{4}$

$\begin{array}{lll}50 & 33.2 \pm 3.0 & 0.65 \\ 50 & 36.0 \pm 3.1 & 0.61 \\ 50 & 47.6 \pm 3.5 & 0.53 \\ \underline{50} & \underline{38.8} \pm \underline{2.8} & \underline{0.50} \\ 200 & 38.9 \pm 1.6 & 0.58\end{array}$



$\begin{array}{lll}50 & 33.7 \pm 2.4 & 0.50\end{array}$

$50 \quad 29.6 \pm 2.5 \quad 0.60$

$50 \quad 35.3 \pm 2.5 \quad 0.50$

$\underline{50} \quad \underline{35.3} \pm \underline{3.4} \quad \underline{0.68}$

$200 \quad 33.4 \pm 1.4 \quad 0.58$

Ave. R1 + R2 $400 \quad 36.2 \pm 7.1 \quad 0.59$

Statistical Comparisons:

No difference between sites

$p \geq .50$

No difference between reps

$p=.23$

Transects different within reps $p=.001$ 

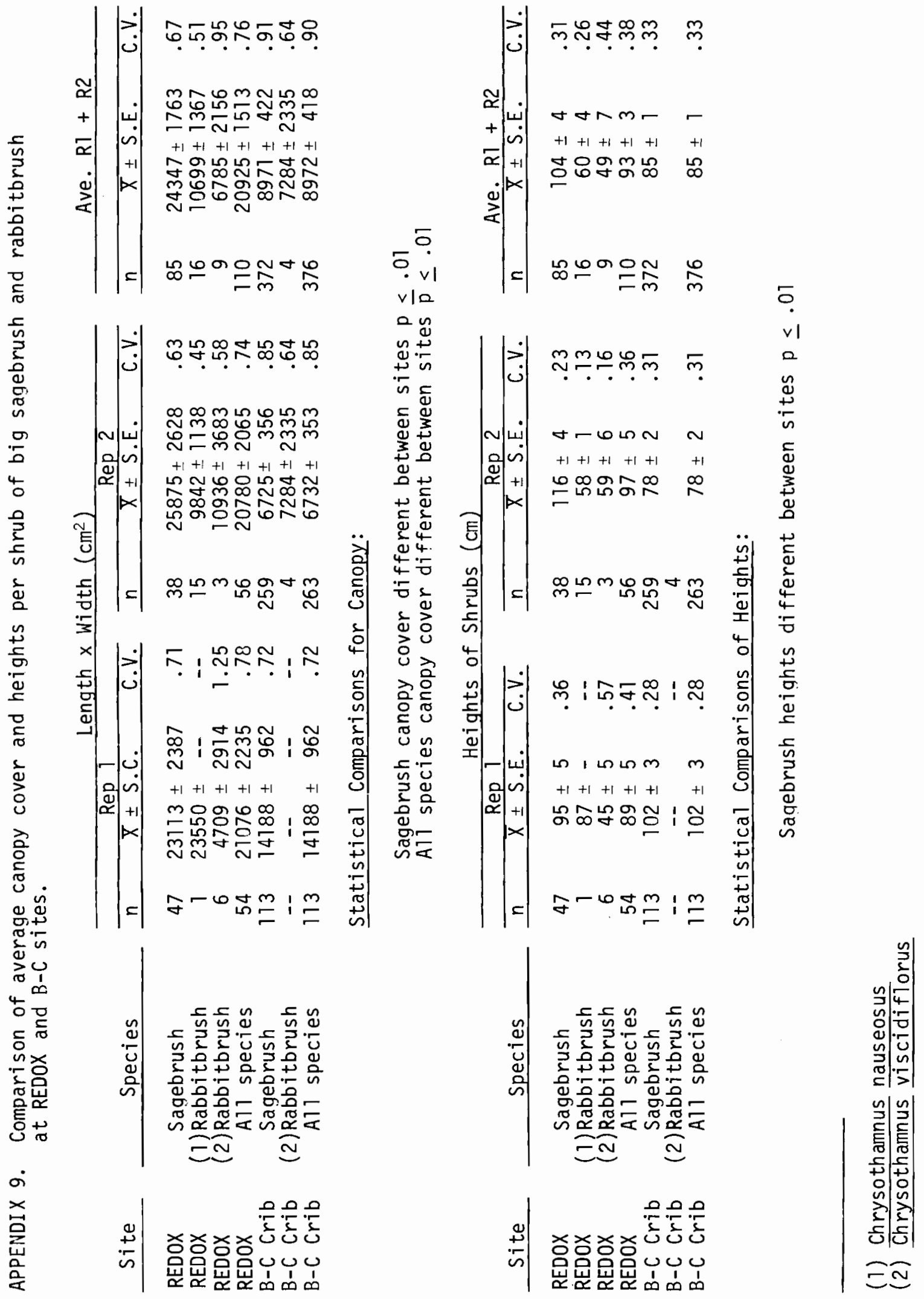
BNWL -1916

UC-70

Special Distribution

DISTRIBUTION LIST

ERDA Chicago Patent Group

Division of Biomedical and Environmental Research, USERDA

J. L. Liverman

C. L. Osterberg

J. Swinebroad

R. L. Watters

ERDA Technical Information Center

Division of Waste Management and Transportation, USERDA

G. H. Daly

F. K. Pittman

R. W. Ramsey

R. A. Wolfe

Division of Production and Materials Management, USERDA

F. P. Baranowskj

D. E. Saire

G. B. Pleat

W. R. Voight, Jr.

Argonne National Laboratory

9700 South Carr Avenue

Argonne, Illinois 60439

Librarian

Brookhaven National Laboratory

Research Library, Reference Section

Upton, L.I., New York 11973 .

E. I. duPont De Nemours and Co.

Aiken

Savannah River Laboratory

Technical Information Service Room 773-A

Aiken, South Carolina 29801

Lawrence Radiation Laboratory

Lawrence Livermore Laboratory

Technical Information Dept., L-3

P. 0. Box 808

Livermore, California 94550 
Los Alamos Scientific Laboratory

P. 0. Box 1663

Los Alamos, New Mexico 87544

W. C. Hanson

Tom Hakonson

1

Oak Ridge National Laboratory

Oak Ridge Operations Office

Oak Ridge, Tennessee 37830

S. I. Auerbach

1 ERDA Nevada Operations Office

P. 0. Box 14100

Las Vegas, Nevada 89114

P. Dunaway

Individuals in the United States

Dr. 0. Doyle Markham

Environmental Sciences Branch

Heal th Services Laboratory

USERDA

P. 0. Box 2108

Idaho Falls, Idaho 83401

Dr. Ward F. Whicker

Radiology and Radiation Biology Department

Colorado State University

Fort Collins, Colorado 80521

Dr. David Willis, Chairman

Department of General Sciences

Oregon State University

Corvallis, Oregon

Dr. Mike Smith, Director

Savannah River Ecology Laboratory

Drawer E

Aiken, South Carolina 29801

Onsite

1 Patent Attorney

$3 \quad$ ERDA/RLO0

O. J. Elgert - D. M. Smith

R. B. Goranson

B. J. Melton - Paul Dunigan 
Battelle Northwest

E. L. Alpen

J. P. Corley

L. L. Eberhardt

W. H. Rickard (5)

W. L. Templeton (5)

C. M. Unruh

B. E. Vaughan (5)

E. L. Klepper (5)

J. F. Cline (5)

D. W. Uresk (5)

Biology Library (3)

Technical Information (5)

Technical Publications (3)

Atlantic Richfield Hanford Company

J. D. Anderson

H. Babad

G. E. Backman

D. J. Brown

L. E. Bruns (3)

G. Burton, Jr.

D. Grudin

G. L. Hanson

M. K. Harmon

W. M. Harty

O. F. Hill

H. H. Hopkins, Jr.

R. E. Isaacson (5)

R. K. Lee

C. W. Malody

H. L. Maxfield

T. R. McKenzie

B. J. McMurray

D. C. Nelson

G. C. Oberg

K. R. Price

H. P. Shaw

R. M. Smithers

G. T. Stocking

V. A. Uresk (5)

W. J. Van Siyke

J. H. Warren

A. T. White

D. D. Wodrich

W. H. Zimmer

R. A. Zins $1 i$ 